\title{
On the Basicity of Carboranylphosphines
}

Amanda Benton, Derek J. Durand, Zachariah Copeland, James D. Watson, Natalie Fey, Stephen M.

Mansell, Georgina M. Rosair, Alan J. Welch

Institute of Chemical Sciences, Heriot-Watt University, Edinburgh EH14 4AS, UK.

and

School of Chemistry, University of Bristol, Cantock's Close, Bristol BS8 1TS, UK.

\section{Supporting Information (SI)}

\section{Contents}

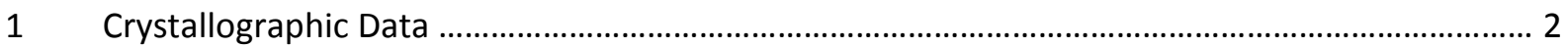

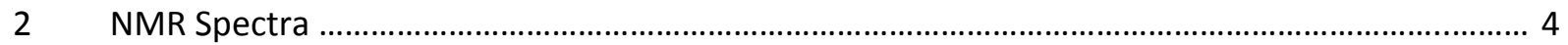

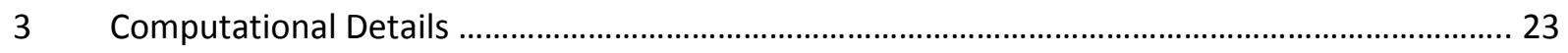

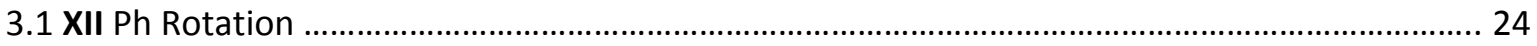

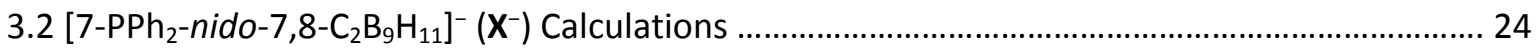

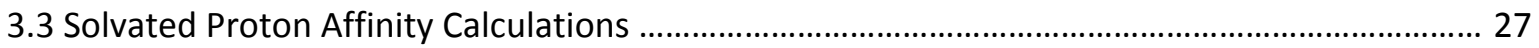

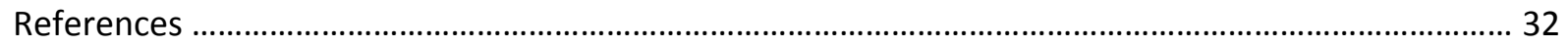




\section{$1 \quad$ Crystallographic Data}

Table S1: Details of the single-crystal structure determinations.

\begin{tabular}{|c|c|c|c|c|c|}
\hline & 2 & [BTMA]X & II & 1Se & $2 \mathrm{Se}_{2}$ \\
\hline CCDC & 1946353 & 1946354 & 1946355 & 1946356 & 1946357 \\
\hline Formula & $\mathrm{C}_{28} \mathrm{H}_{40} \mathrm{~B}_{20} \mathrm{P}_{2}$ & $\mathrm{C}_{24} \mathrm{H}_{37} \mathrm{~B}_{9} \mathrm{NP}$ & $\mathrm{C}_{14} \mathrm{H}_{21} \mathrm{~B}_{10} \mathrm{P}$ & $\mathrm{C}_{16} \mathrm{H}_{31} \mathrm{~B}_{20} \mathrm{PSe}$ & $\mathrm{C}_{28} \mathrm{H}_{40} \mathrm{~B}_{20} \mathrm{P}_{2} \mathrm{Se}_{2}$ \\
\hline$M$ & 654.74 & 467.80 & 328.38 & 549.54 & 812.66 \\
\hline Crystal system & Triclinic & Monoclinic & Monoclinic & Triclinic & Monoclinic \\
\hline Space group & $P \overline{1}$ & $P 2_{1} / n$ & $P 2_{1} / c$ & $P \overline{1}$ & $P 2_{1} / c$ \\
\hline$a / \AA$ & $8.8455(7)$ & $12.8750(11)$ & $10.7605(9)$ & $10.6563(8)$ & $13.4421(6)$ \\
\hline$b / \AA$ & $9.5906(7)$ & $10.2839(8)$ & $14.8031(12)$ & $11.1027(8)$ & $13.5712(5)$ \\
\hline$c / \AA ̊$ & $11.6204(8)$ & $20.5590(18)$ & $12.3879(9)$ & $14.0115(11)$ & $10.5901(4)$ \\
\hline$\alpha /^{\circ}$ & $71.047(4)$ & 90 & 90 & $87.453(6)$ & 90 \\
\hline$\beta /^{\circ}$ & $89.380(4)$ & $91.929(4)$ & $109.978(2)$ & $68.577(7)$ & $105.633(4)$ \\
\hline $\mathrm{V} /{ }^{\circ}$ & $72.930(4)$ & 90 & 90 & $61.884(7)$ & 90 \\
\hline$U / \AA^{3}$ & $887.38(12)$ & $2720.6(4)$ & $1854.5(3)$ & $1344.6(2)$ & $1860.44(13)$ \\
\hline$Z, Z^{\prime}$ & $1,0.5$ & 4,1 & 4,1 & 2,1 & $2,0.5$ \\
\hline$F(000) / e$ & 338 & 992 & 680 & 552 & 812 \\
\hline$D_{\text {calc }} / \mathrm{Mg} \mathrm{m}^{-3}$ & 1.225 & 1.142 & 1.176 & 1.357 & 1.451 \\
\hline$X$-radiation & Mo- $K_{\alpha}$ & Mo- $K_{\alpha}$ & Mo- $K_{\alpha}$ & Mo- $K_{\alpha}$ & Mo-K $K_{\alpha}$ \\
\hline$\lambda / \AA$ & 0.71073 & 0.71073 & 0.71073 & 0.71073 & 0.71073 \\
\hline$\mu / \mathrm{mm}^{-1}$ & 0.146 & 0.116 & 0.140 & 1.466 & 2.098 \\
\hline$\theta_{\max } /^{\circ}$ & 26.03 & 26.00 & 28.30 & 28.88 & 29.71 \\
\hline Data measured & 24240 & 38985 & 25477 & 21920 & 17275 \\
\hline Unique data & 3479 & 5331 & 4600 & 6152 & 4611 \\
\hline$R_{\text {int }}$ & 0.0901 & 0.0687 & 0.0539 & 0.0682 & 0.0477 \\
\hline$R, \mathrm{w} R_{2}$ (obs. data) & $0.0600,0.1177$ & $0.0458,0.1097$ & $0.0422,0.1097$ & $0.0533,0.0890$ & $0.0411,0.0769$ \\
\hline$S$ & 1.047 & 1.030 & 1.059 & 1.096 & 1.082 \\
\hline Variables & 257 & 352 & 259 & 406 & 265 \\
\hline$E_{\max }, E_{\min } / \mathrm{e} \AA^{-3}$ & $0.35,-0.35$ & $0.61,-0.43$ & $0.36,-0.24$ & $0.55,-0.51$ & $0.64,-0.36$ \\
\hline Flack parameter & - & - & - & - & - \\
\hline
\end{tabular}




\begin{tabular}{|c|c|c|c|c|}
\hline $3 \mathrm{Se}$ & $4 \mathrm{Se} \cdot 0.5 \mathrm{C}_{6} \mathrm{H}_{14}$ & [BTMA]XSe & IISe & $\mathrm{VIISe}_{2}$ \\
\hline 1946358 & 1946359 & 1946360 & 1946361 & 1946362 \\
\hline $\mathrm{C}_{6} \mathrm{H}_{21} \mathrm{~B}_{10} \mathrm{PSe}$ & $\mathrm{C}_{13} \mathrm{H}_{34} \mathrm{~B}_{20} \mathrm{PSe}$ & $\mathrm{C}_{24} \mathrm{H}_{37} \mathrm{~B}_{9} \mathrm{NPSe}$ & $\mathrm{C}_{14} \mathrm{H}_{21} \mathrm{~B}_{10} \mathrm{PSe}$ & $\mathrm{C}_{26} \mathrm{H}_{30} \mathrm{~B}_{10} \mathrm{P}_{2} \mathrm{Se}_{2}$ \\
\hline 311.26 & 516.53 & 546.76 & 407.34 & 670.46 \\
\hline Monoclinic & Monoclinic & Orthorhombic & Monoclinic & Monoclinic \\
\hline$P 2_{1} / n$ & $P 2_{1} / n$ & $P 2_{1} 2_{1} 2_{1}$ & $P 2_{1} / c$ & $P 2_{1} / c$ \\
\hline $6.8125(3)$ & $11.42485(7)$ & $9.7581(3)$ & 17.3854(9) & $18.2162(7)$ \\
\hline 19.1019(9) & $16.90881(11)$ & $15.3772(5)$ & 13.8292(6) & $9.5634(4)$ \\
\hline $11.6526(6)$ & $14.25446(9)$ & $18.9355(5)$ & 17.3988(9) & 17.8339(7) \\
\hline 90 & 90 & 90 & 90 & 90 \\
\hline $93.539(3)$ & $105.9360(6)$ & 90 & $112.5818(18)$ & $107.205(2)$ \\
\hline 90 & 90 & 90 & 90 & 90 \\
\hline $1513.48(12)$ & $2647.86(3)$ & $2841.31(15)$ & $3862.4(3)$ & $2967.8(2)$ \\
\hline 4,1 & 4,1 & 4,1 & 8,2 & 4,1 \\
\hline 624 & 1044 & 1128 & 1632 & 1336 \\
\hline 1.366 & 1.296 & 1.278 & 1.401 & 1.501 \\
\hline Mo- $K_{\alpha}$ & $\mathrm{Cu}-K_{\alpha}$ & Mo- $K_{\alpha}$ & Mo- $K_{\alpha}$ & Mo- $K_{\alpha}$ \\
\hline 0.71073 & 1.54184 & 0.71073 & 0.71073 & 0.71073 \\
\hline 2.555 & 2.478 & 1.393 & 2.022 & 2.618 \\
\hline 28.03 & 76.03 & 31.08 & 31.03 & 32.29 \\
\hline 25523 & 21467 & 69917 & 51928 & 79369 \\
\hline 3656 & 5466 & 9071 & 12504 & 10455 \\
\hline 0.0667 & 0.0520 & 0.0634 & 0.0498 & 0.0465 \\
\hline $0.0728,0.1877$ & $0.0509,0.1419$ & $0.0286,0.0578$ & $0.0349,0.0673$ & $0.0274,0.0614$ \\
\hline 1.053 & 1.066 & 1.032 & 1.039 & 1.028 \\
\hline 202 & 384 & 362 & 536 & 391 \\
\hline $3.26,^{a}-1.40^{b}$ & $0.58,-0.89$ & $0.35,-0.35$ & $0.89,-0.49$ & $0.49,-0.52$ \\
\hline- & - & $0.390(6)$ & - & - \\
\hline
\end{tabular}

${ }^{a} 0.86 \AA$ from Se1. ${ }^{b} 0.71 \AA$ from Se1. 
$2 \quad$ NMR Spectra

* $\mathrm{CH}_{2} \mathrm{Cl}_{2}$

$\% \mathrm{H}_{2} \mathrm{O}$

$\diamond \mathrm{H}$-grease/petrol residues

$\neq\left(\mathrm{CH}_{3}\right)_{2} \mathrm{CO}$

[1- $\left(1^{\prime}-\right.$ closo- $\left.1^{\prime}, 7^{\prime}-\mathrm{C}_{2} \mathrm{~B}_{10} \mathrm{H}_{11}\right)-7-\mathrm{PPh}_{2}-$ closo-1,7- $\left.\mathrm{C}_{2} \mathrm{~B}_{10} \mathrm{H}_{10}\right](\mathbf{1})$

${ }^{1} \mathrm{H} \mathrm{NMR}\left(\mathrm{CDCl}_{3}\right)$ :

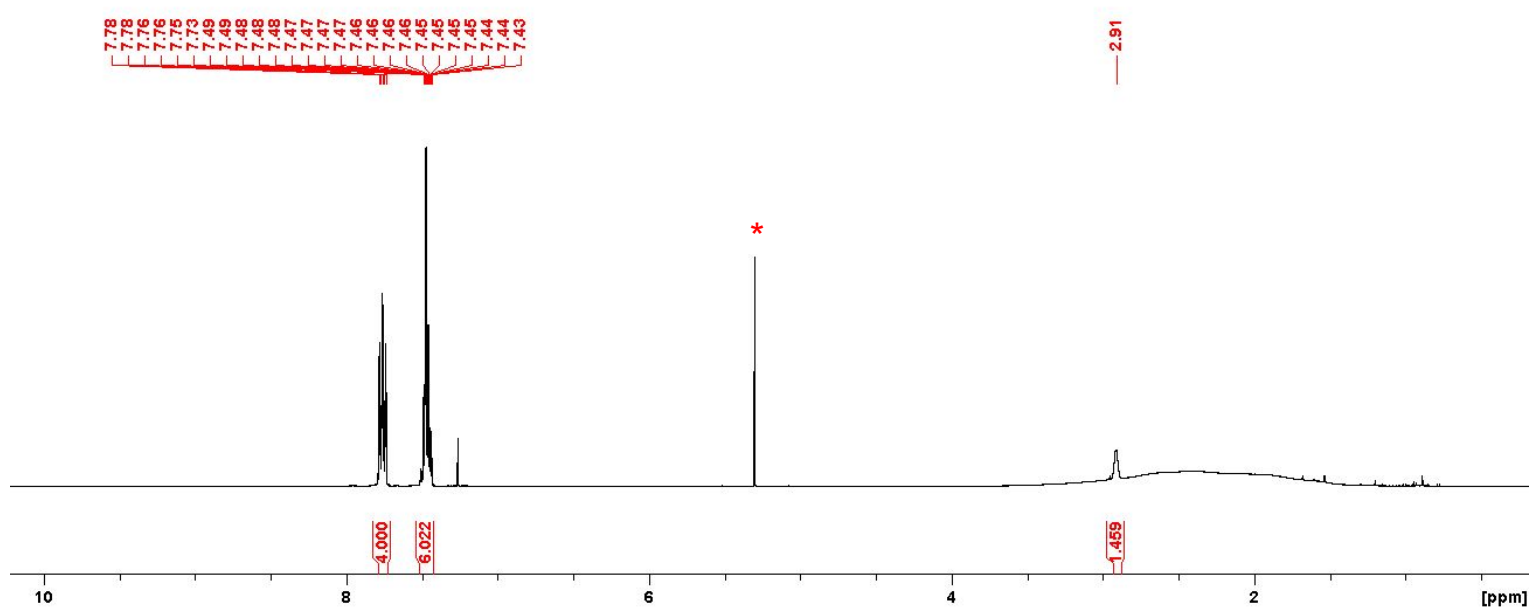

${ }^{11} \mathrm{~B}\left\{{ }^{1} \mathrm{H}\right\}$ NMR spectrum of $1\left(\mathrm{CDCl}_{3}\right)$ :

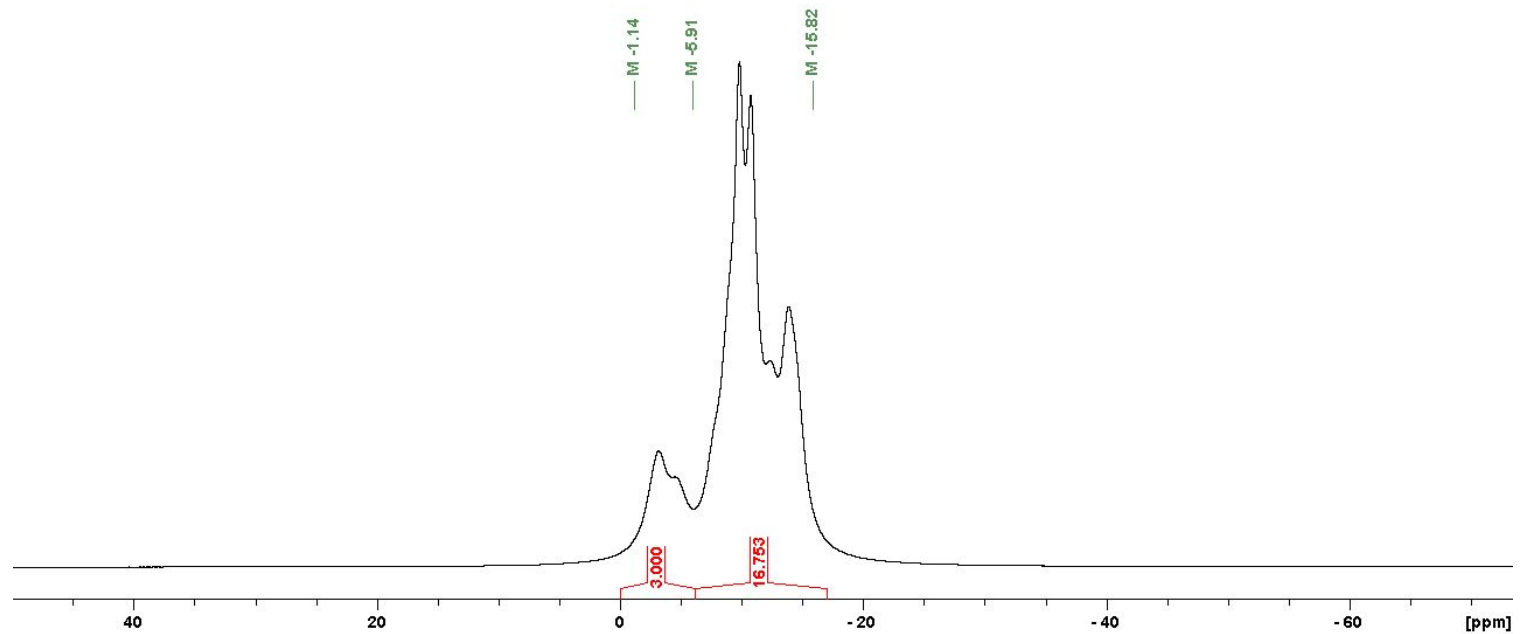


${ }^{31} \mathrm{P}\left\{{ }^{1} \mathrm{H}\right\}$ NMR spectrum of $\mathbf{1}\left(\mathrm{CDCl}_{3}\right)$ :

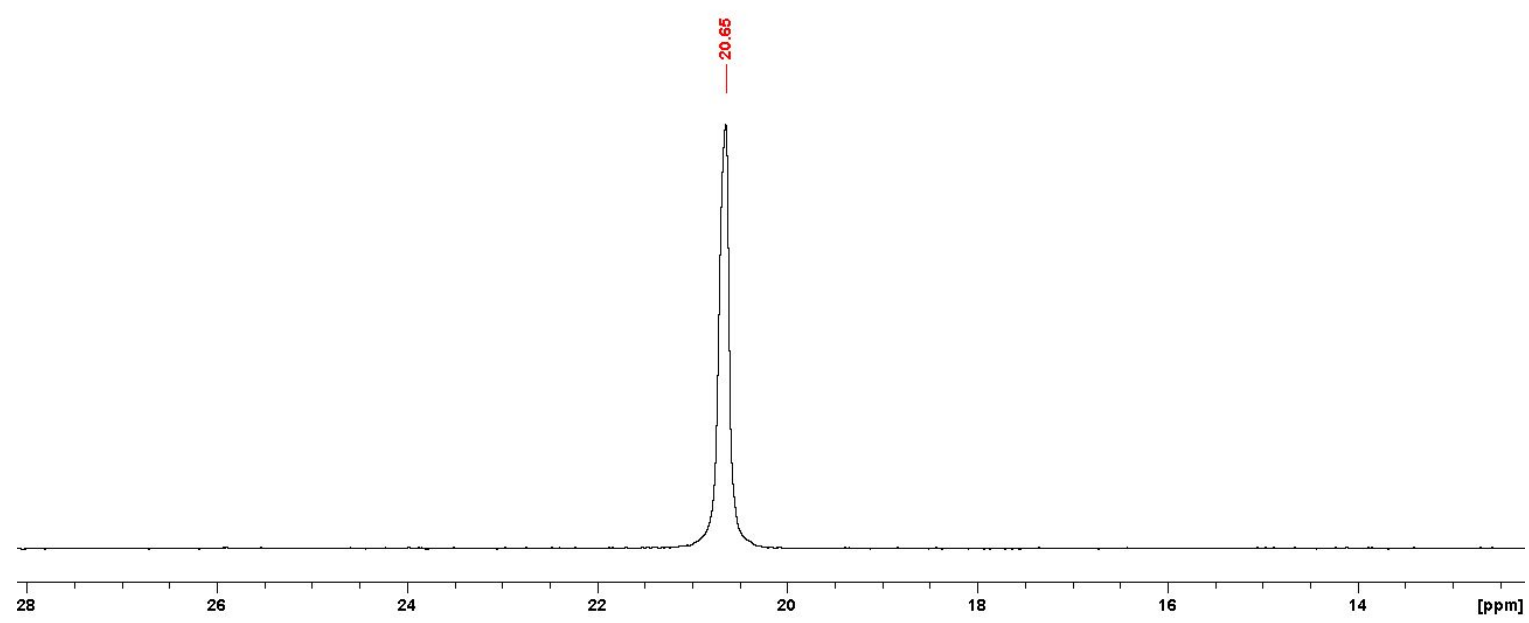

[1- $\left(1^{\prime}-7^{\prime}-\mathrm{PPh}_{2}\right.$-closo-1', 7' $\left.^{\prime}-\mathrm{C}_{2} \mathrm{~B}_{10} \mathrm{H}_{10}\right)-7-\mathrm{PPh}_{2}$-closo-1,7- $\left.\mathrm{C}_{2} \mathrm{~B}_{10} \mathrm{H}_{10}\right](2)$

${ }^{1} \mathrm{H} \mathrm{NMR}\left(\mathrm{CDCl}_{3}\right)$ :

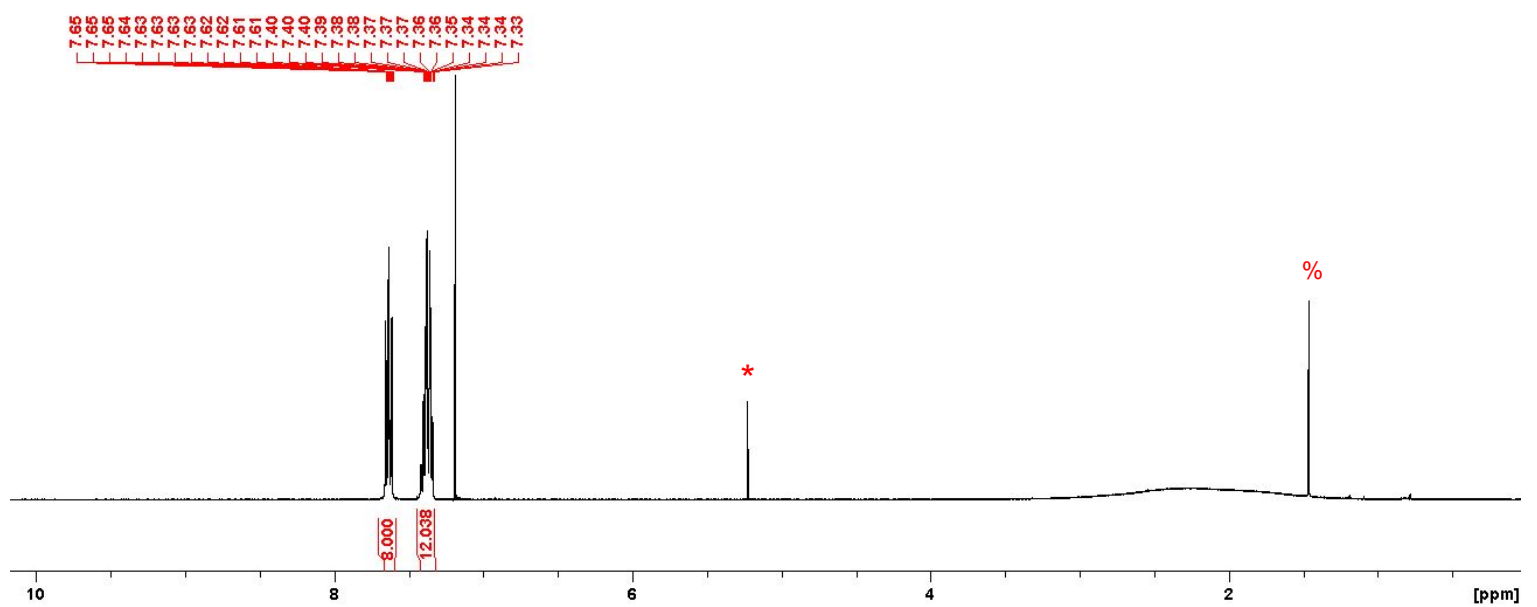


${ }^{11} \mathrm{~B}\left\{{ }^{1} \mathrm{H}\right\}$ NMR spectrum of $\mathbf{2}\left(\mathrm{CDCl}_{3}\right)$ :

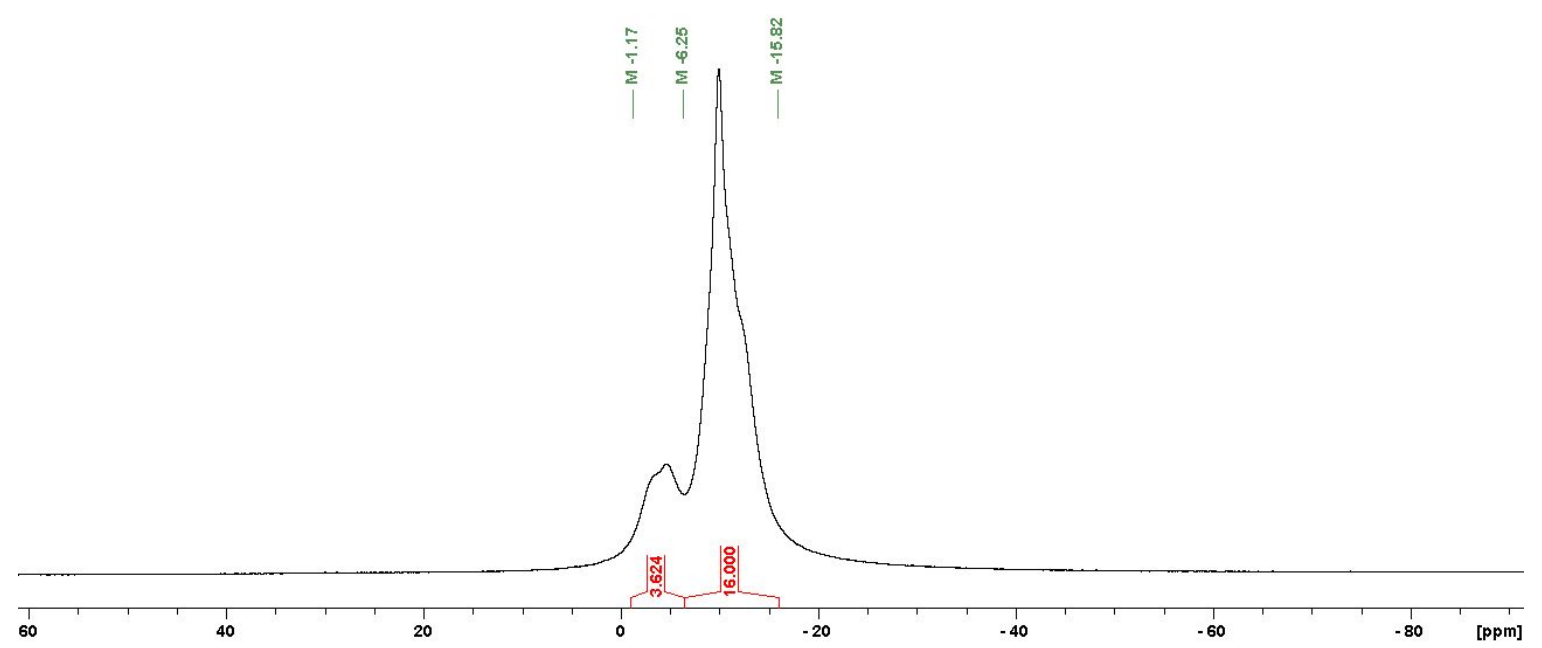

${ }^{31} \mathrm{P}\left\{{ }^{1} \mathrm{H}\right\}$ NMR spectrum of $\mathbf{2}\left(\mathrm{CDCl}_{3}\right)$ :

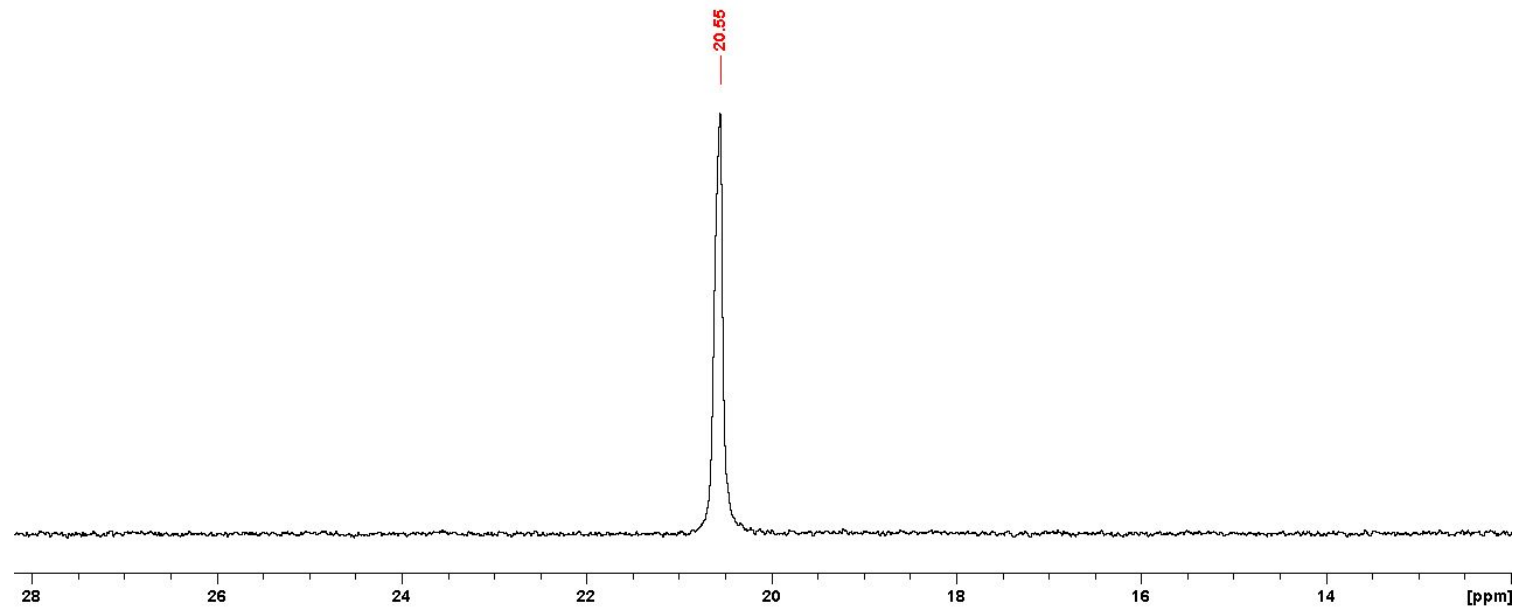


[1- $\left\{\right.$ PPh- $\left(1^{\prime}\right.$-closo- $\left.\left.1^{\prime}, 2^{\prime}-\mathrm{C}_{2} \mathrm{~B}_{10} \mathrm{H}_{11}\right)\right\}$-closo-1,2- $\left.\mathrm{C}_{2} \mathrm{~B}_{10} \mathrm{H}_{11}\right](4)$

${ }^{1} \mathrm{H} \mathrm{NMR}\left(\mathrm{CDCl}_{3}\right)$ :

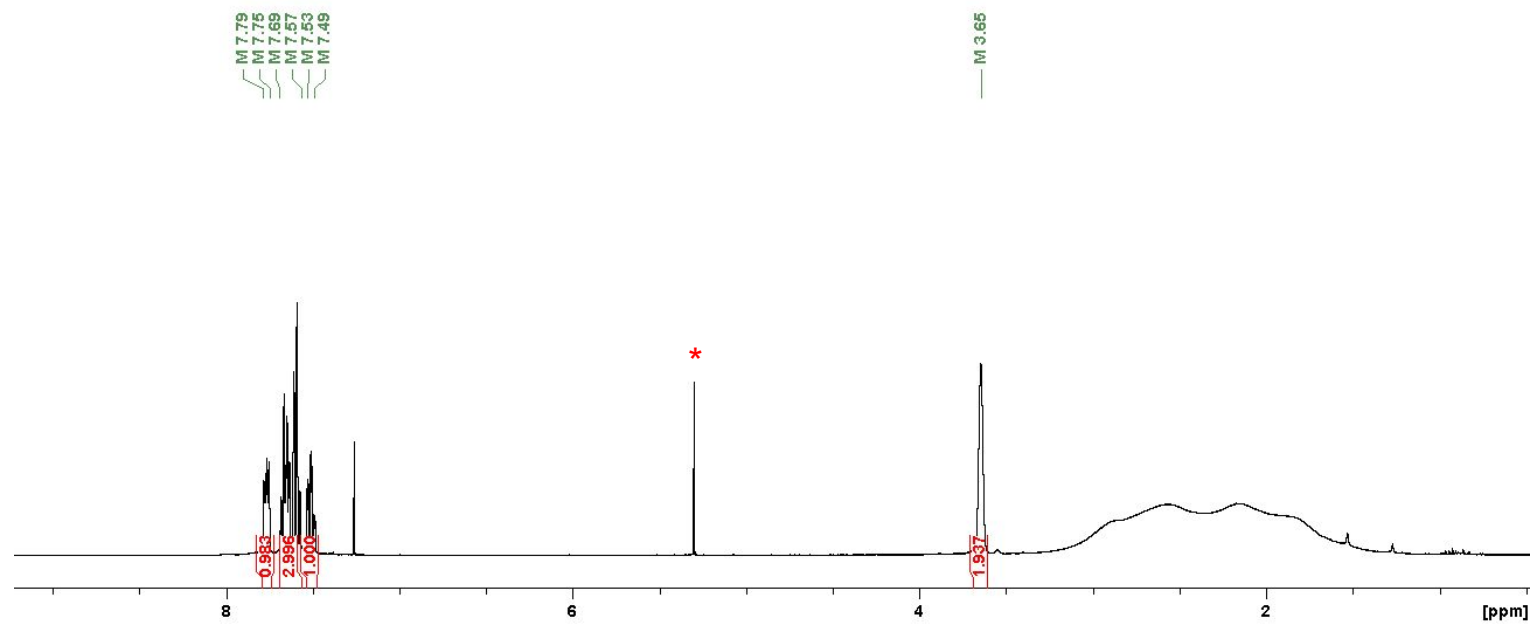

${ }^{11} \mathrm{~B}\left\{{ }^{1} \mathrm{H}\right\}$ NMR spectrum of $4\left(\mathrm{CDCl}_{3}\right)$ :

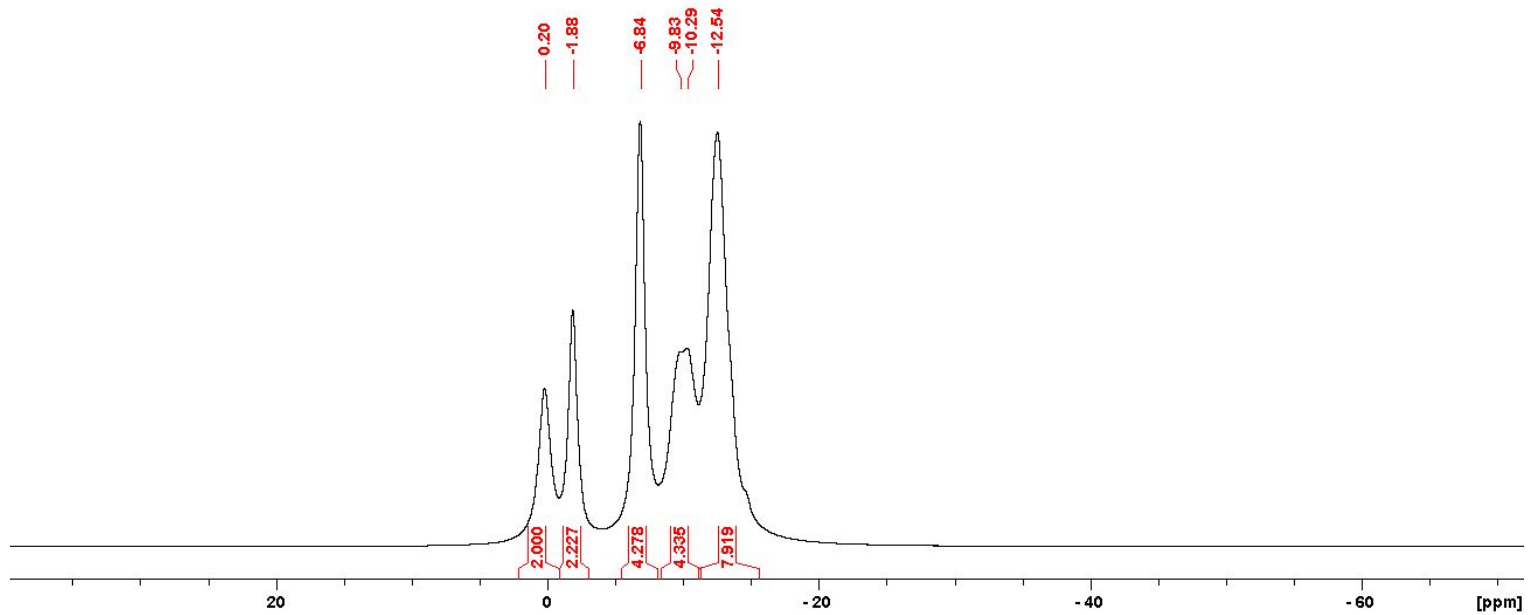


${ }^{31} \mathrm{P}\left\{{ }^{1} \mathrm{H}\right\}$ NMR spectrum of $4\left(\mathrm{CDCl}_{3}\right)$ :

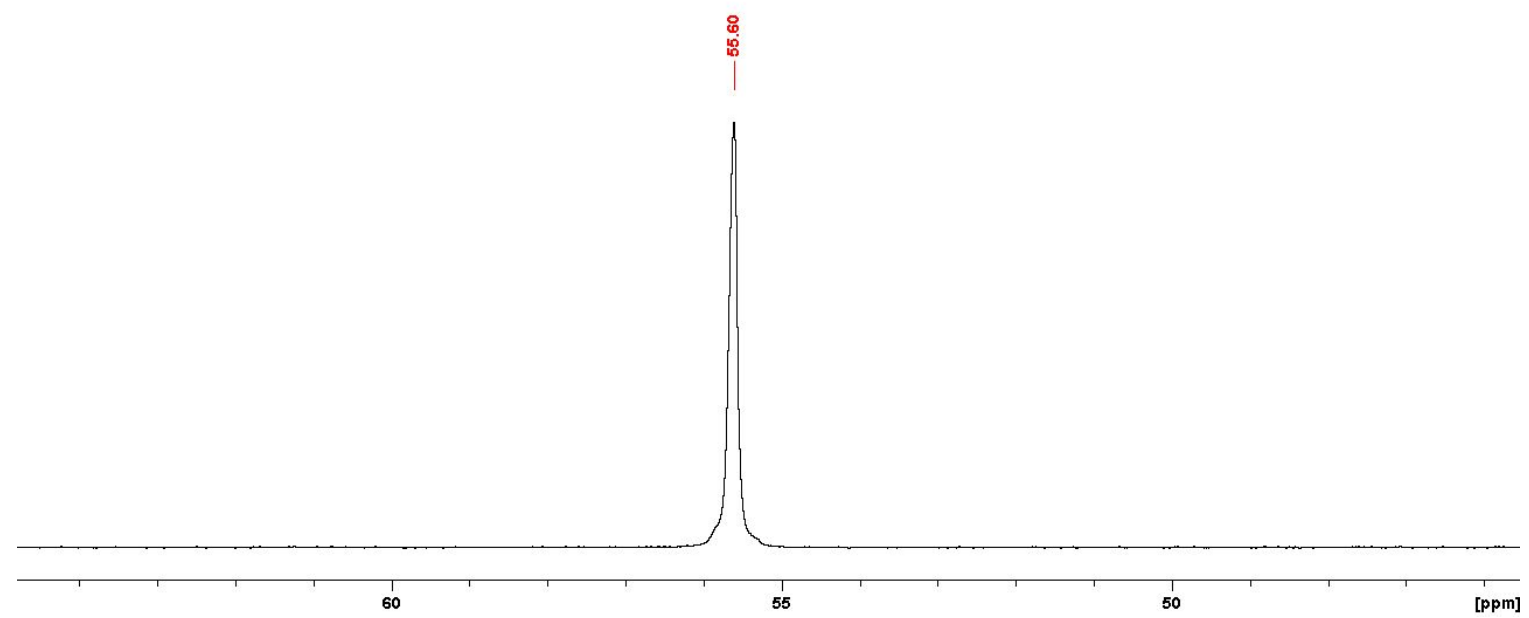

[BTMA][7-PPh 2 -nido-7,8- $\left.\mathrm{C}_{2} \mathrm{~B}_{9} \mathrm{H}_{11}\right]$ ([BTMA]X)

${ }^{1} \mathrm{H}$ NMR $\left[\left(\mathrm{CD}_{3}\right)_{2} \mathrm{CO}\right]$ :

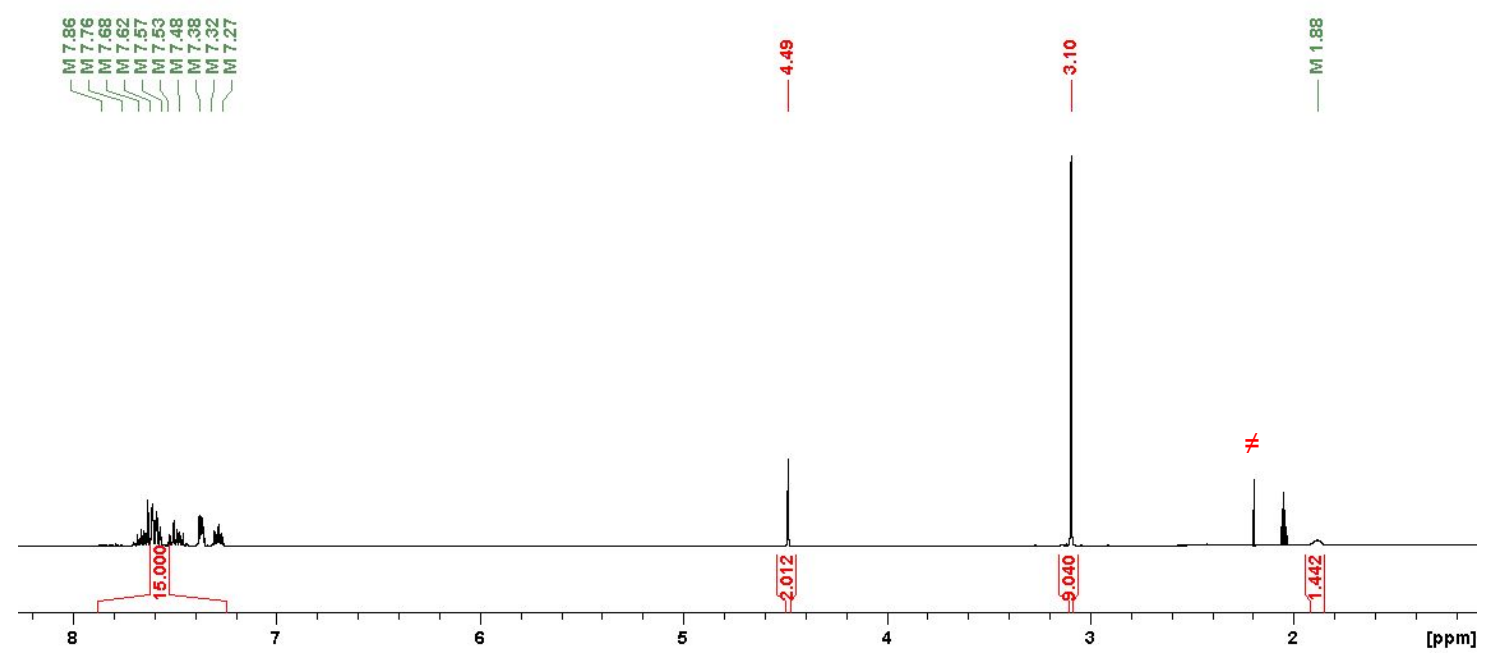


${ }^{11} \mathrm{~B}\left\{{ }^{1} \mathrm{H}\right\}$ NMR spectrum of [BTMA]X $\left[\left(\mathrm{CD}_{3}\right)_{2} \mathrm{CO}\right]$ :

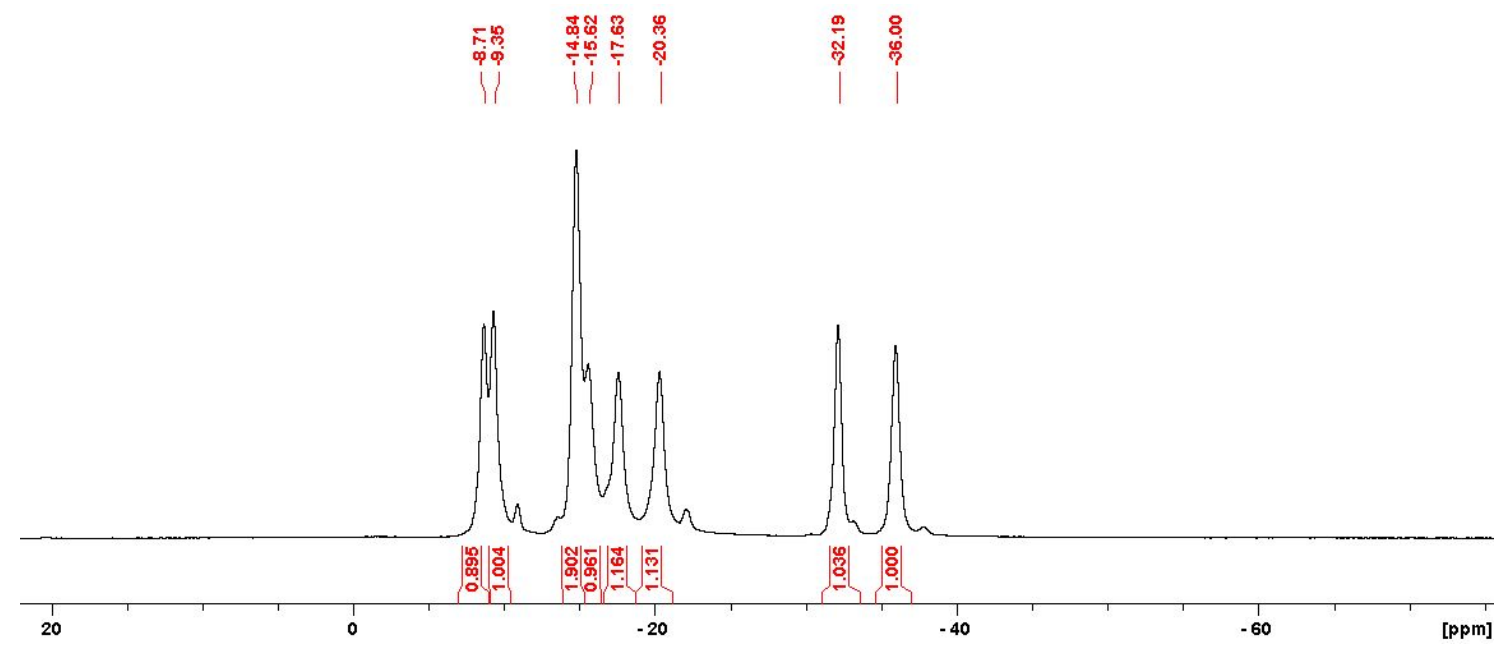

${ }^{31} \mathrm{P}\left\{{ }^{1} \mathrm{H}\right\}$ NMR spectrum of [BTMA $] \mathbf{X}\left[\left(\mathrm{CD}_{3}\right)_{2} \mathrm{CO}\right]$ :

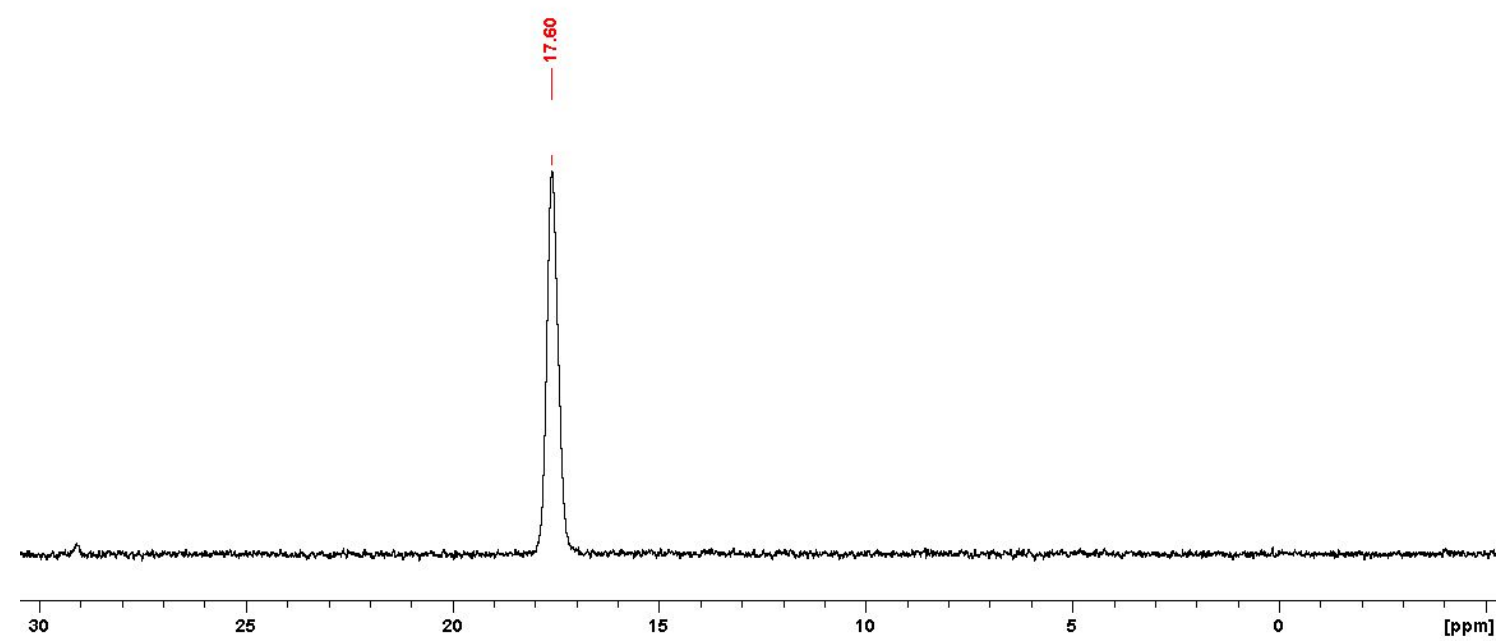


[1-P(Se) $\mathrm{Ph}_{2}$-closo-1,7- $\mathrm{C}_{2} \mathrm{~B}_{10} \mathrm{H}_{11}$ ] (IISe)

${ }^{1} \mathrm{H} \mathrm{NMR}\left(\mathrm{CDCl}_{3}\right)$ :

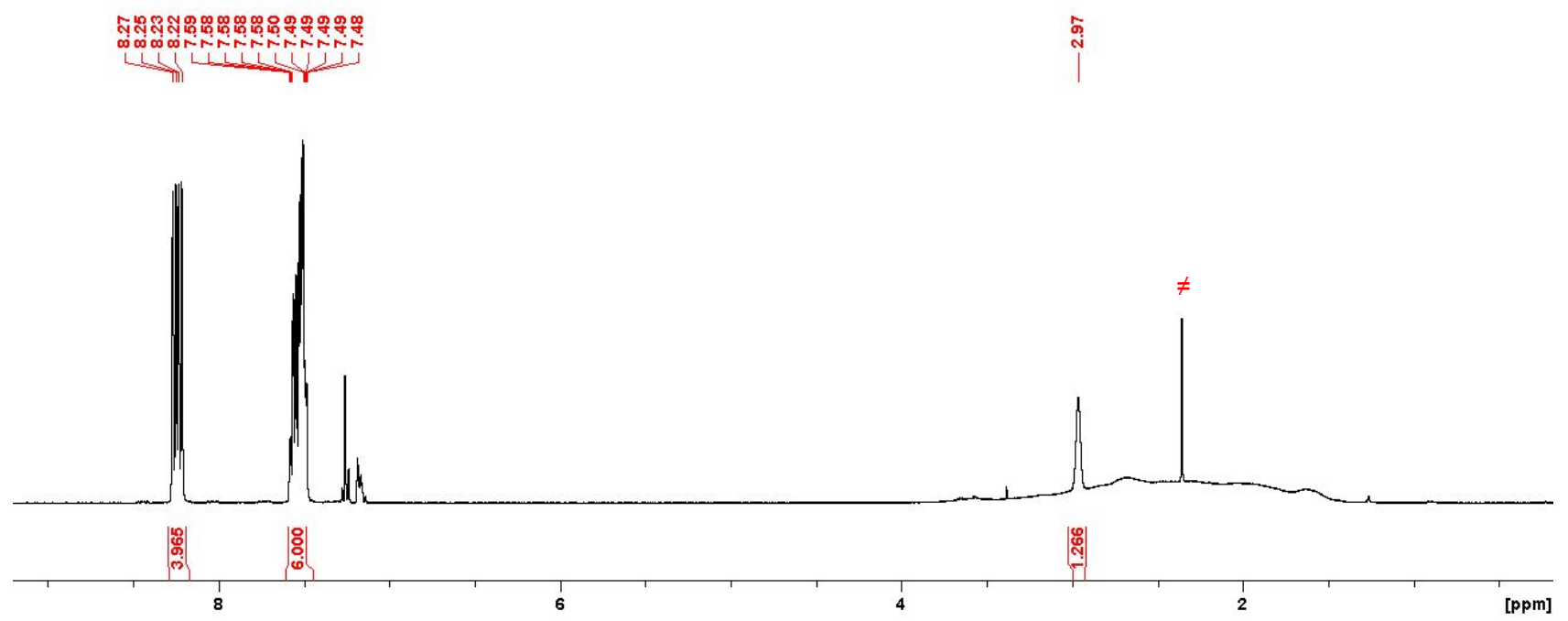

${ }^{11} \mathrm{~B}\left\{{ }^{1} \mathrm{H}\right\}$ NMR spectrum of IISe $\left(\mathrm{CDCl}_{3}\right)$ :

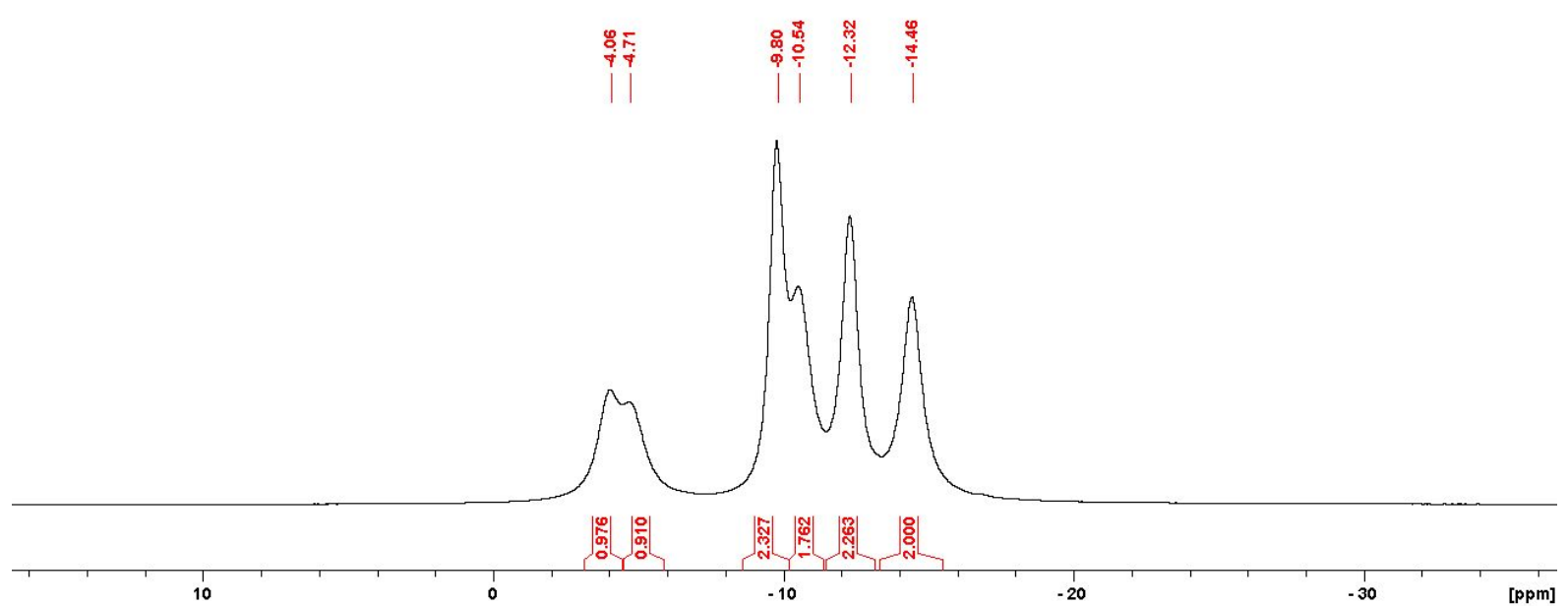


${ }^{31} \mathrm{P}\left\{{ }^{1} \mathrm{H}\right\}$ NMR spectrum of IISe $\left(\mathrm{CDCl}_{3}\right)$ :

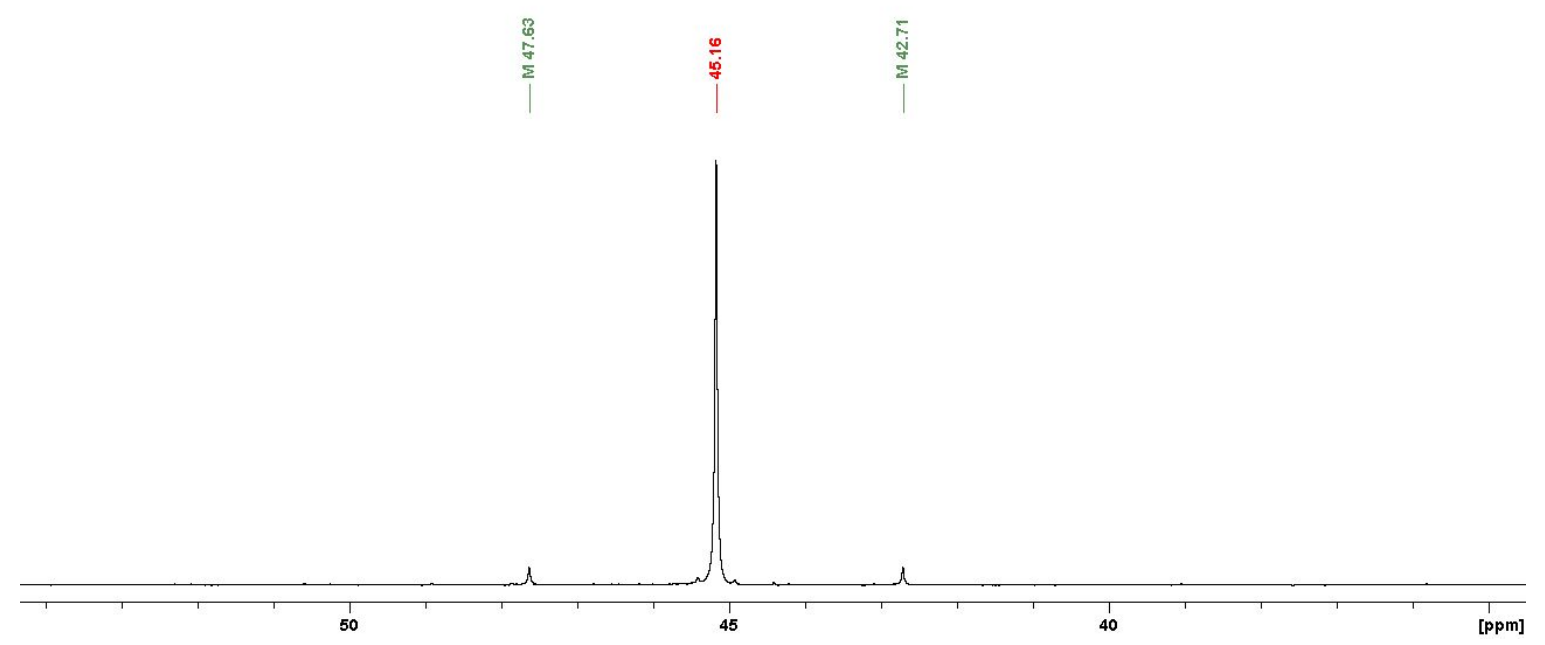

$\left[1,7-\left\{\mathrm{P}(\mathrm{Se}) \mathrm{Ph}_{2}\right\}_{2}\right.$-closo-1,7- $\left.\mathrm{C}_{2} \mathrm{~B}_{10} \mathrm{H}_{10}\right]\left(\mathrm{VIISe}_{2}\right)$

${ }^{1} \mathrm{H}$ NMR $\left(\mathrm{CDCl}_{3}\right)$ :

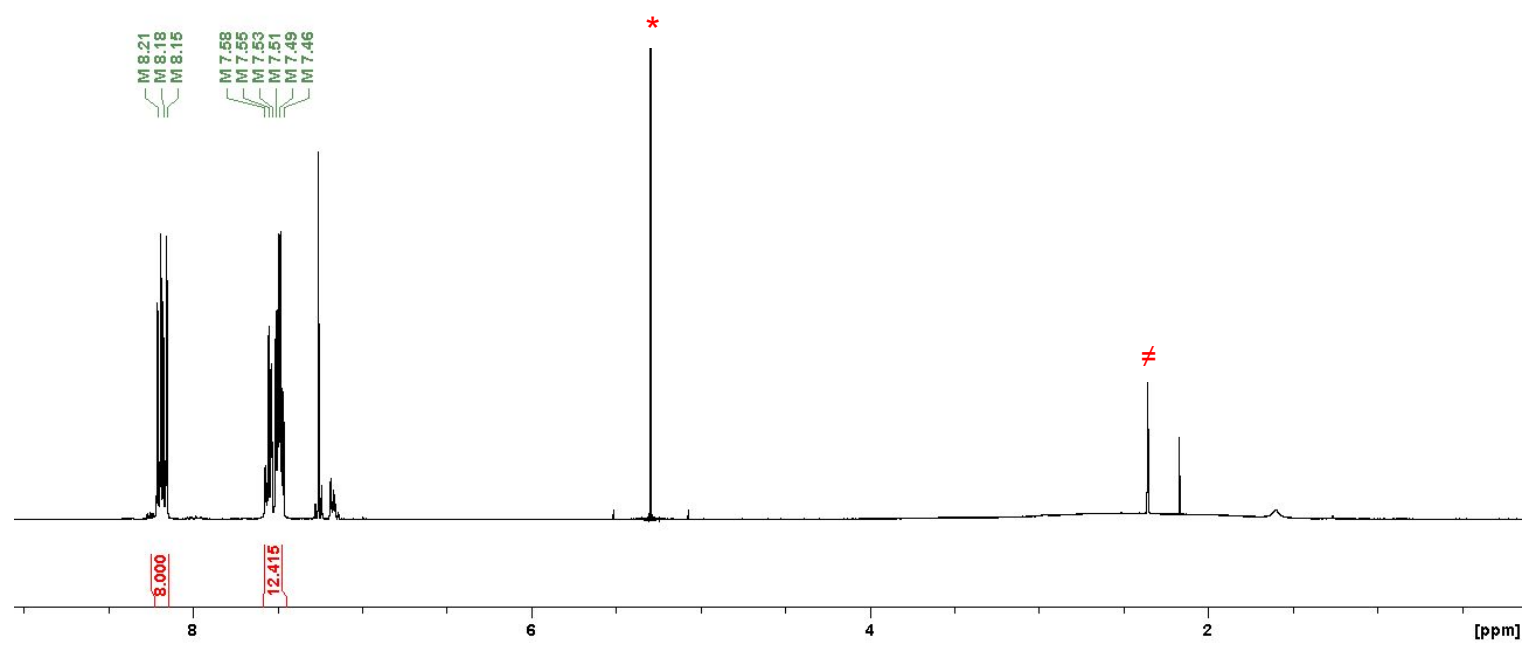


${ }^{11} \mathrm{~B}\left\{{ }^{1} \mathrm{H}\right\}$ NMR spectrum of $\mathrm{VIISe}_{\mathbf{2}}\left(\mathrm{CDCl}_{3}\right)$ :

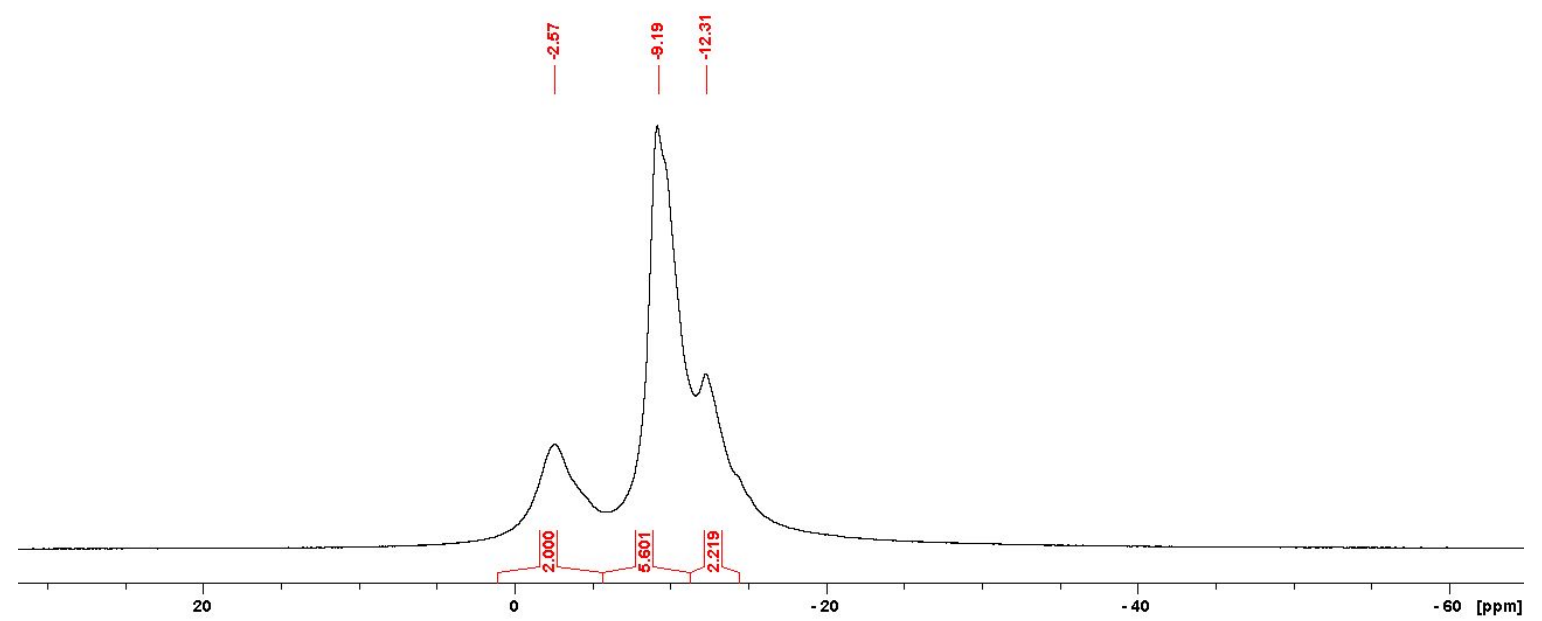

${ }^{31} \mathrm{P}\left\{{ }^{1} \mathrm{H}\right\}$ NMR spectrum of $\mathrm{VIISe}_{\mathbf{2}}\left(\mathrm{CDCl}_{3}\right)$ :

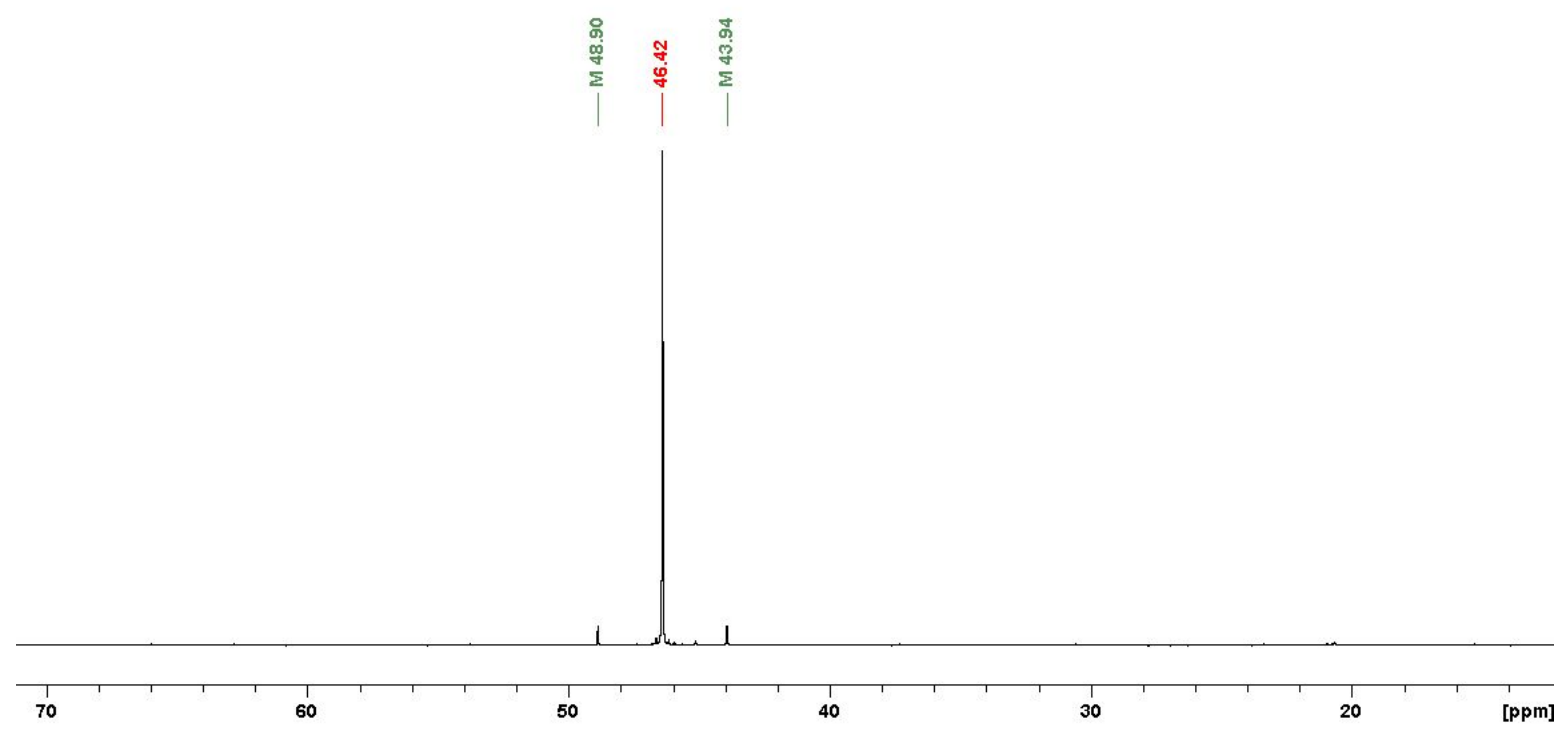


[1- $\left(1^{\prime}-7^{\prime}-\mathrm{P}(\mathrm{Se}) \mathrm{Ph}_{2}\right.$-closo-1', $\left.7^{\prime}-\mathrm{C}_{2} \mathrm{~B}_{10} \mathrm{H}_{10}\right)-7-\mathrm{P}(\mathrm{Se}) \mathrm{Ph}_{2}$-closo-1,7- $\left.\mathrm{C}_{2} \mathrm{~B}_{10} \mathrm{H}_{10}\right]\left(2 \mathrm{Se}_{2}\right)$

${ }^{1} \mathrm{H} \mathrm{NMR}\left(\mathrm{CDCl}_{3}\right)$ :

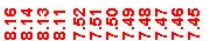

vif

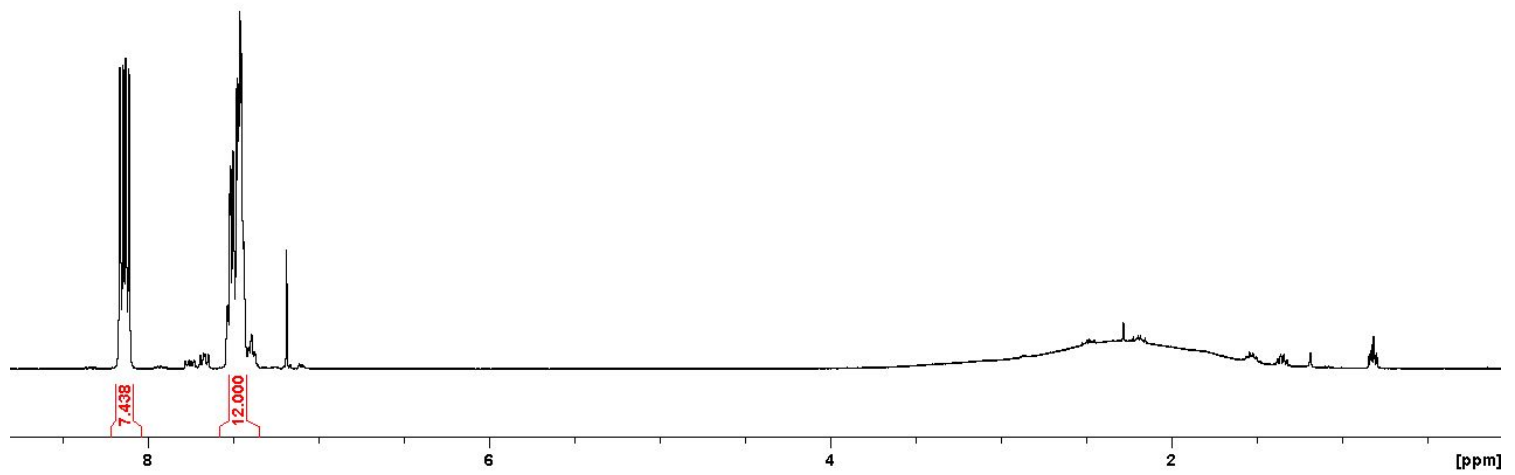

${ }^{11} \mathrm{~B}\left\{{ }^{1} \mathrm{H}\right\}$ NMR spectrum of $\mathbf{2} \mathrm{Se}_{\mathbf{2}}\left(\mathrm{CDCl}_{3}\right)$ :

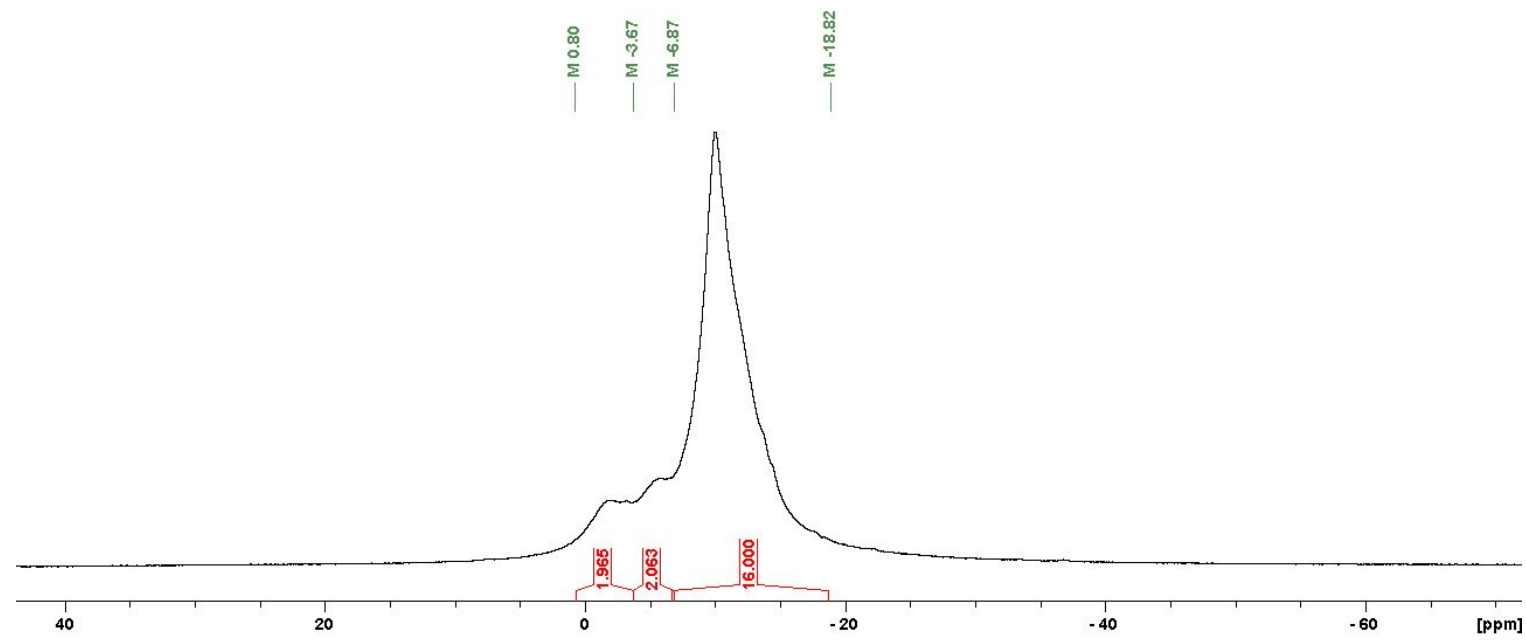


${ }^{31} \mathrm{P}\left\{{ }^{1} \mathrm{H}\right\}$ NMR spectrum of $\mathbf{2} \mathrm{Se}_{\mathbf{2}}\left(\mathrm{CDCl}_{3}\right)$ :

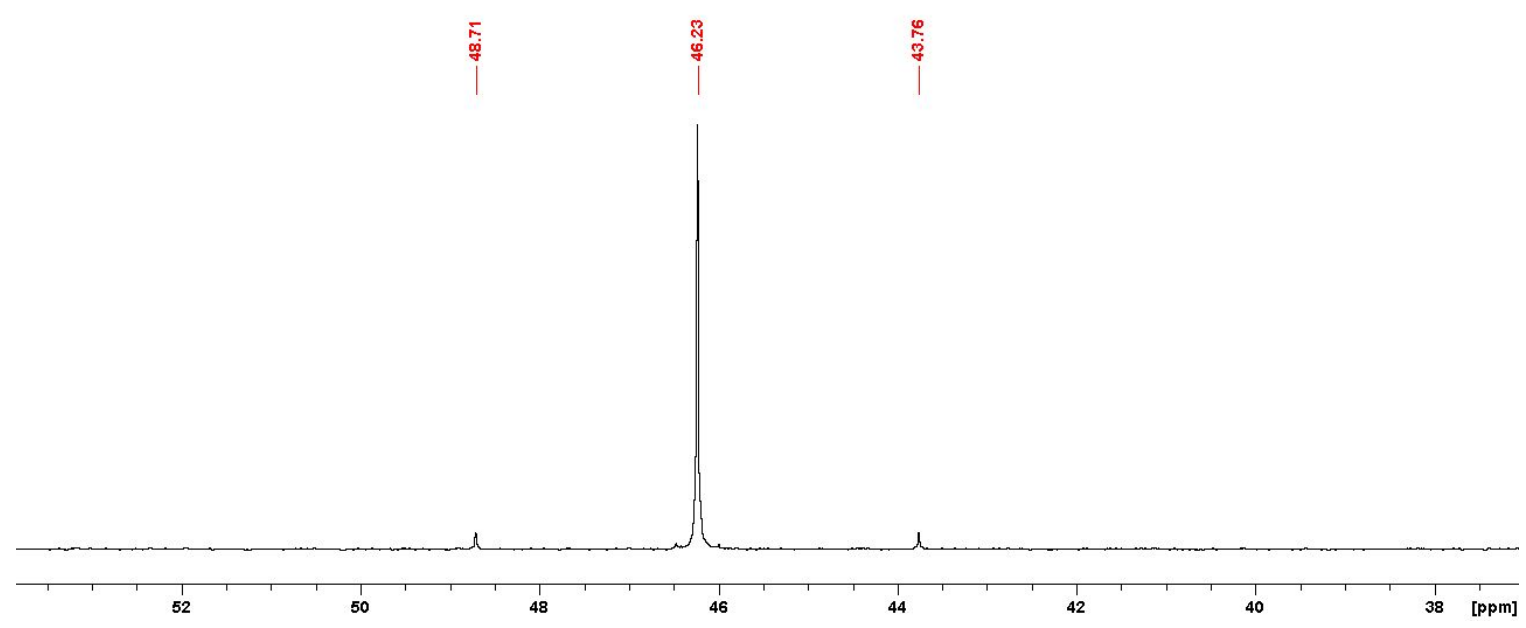

[1- $\left\{\mathrm{P}(\mathrm{Se}) \mathrm{Ph}-\left(1^{\prime}\right.\right.$-closo- $\left.\left.1^{\prime}, 2^{\prime}-\mathrm{C}_{2} \mathrm{~B}_{10} \mathrm{H}_{11}\right)\right\}-$ closo-1,2- $\left.\mathrm{C}_{2} \mathrm{~B}_{10} \mathrm{H}_{11}\right](4 \mathrm{Se})$

${ }^{1} \mathrm{H} \mathrm{NMR}\left(\mathrm{CDCl}_{3}\right)$ :

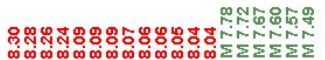

ஸ

in

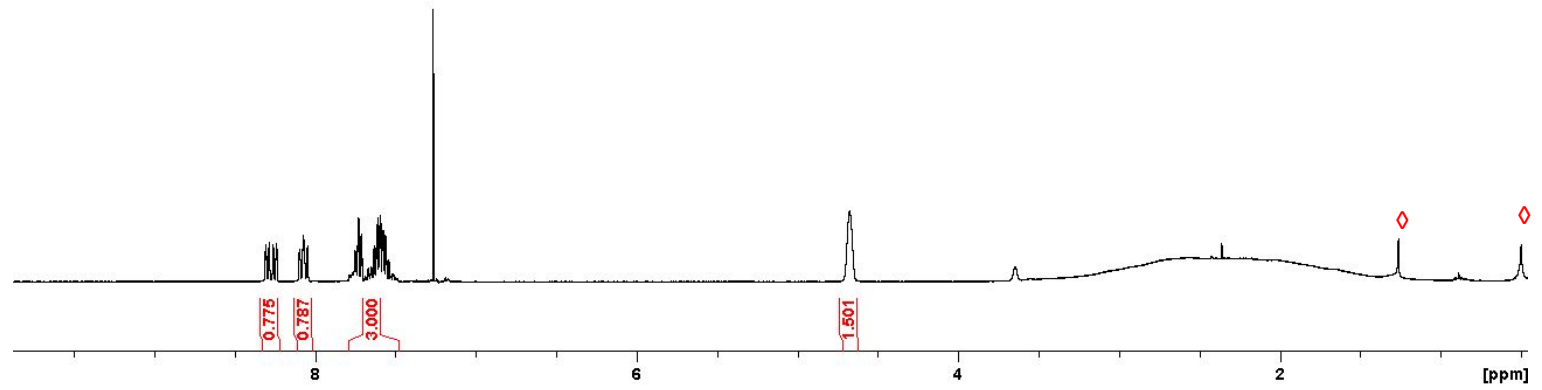


${ }^{11} \mathrm{~B}\left\{{ }^{1} \mathrm{H}\right\}$ NMR spectrum of $4 \mathrm{Se}\left(\mathrm{CDCl}_{3}\right)$ :

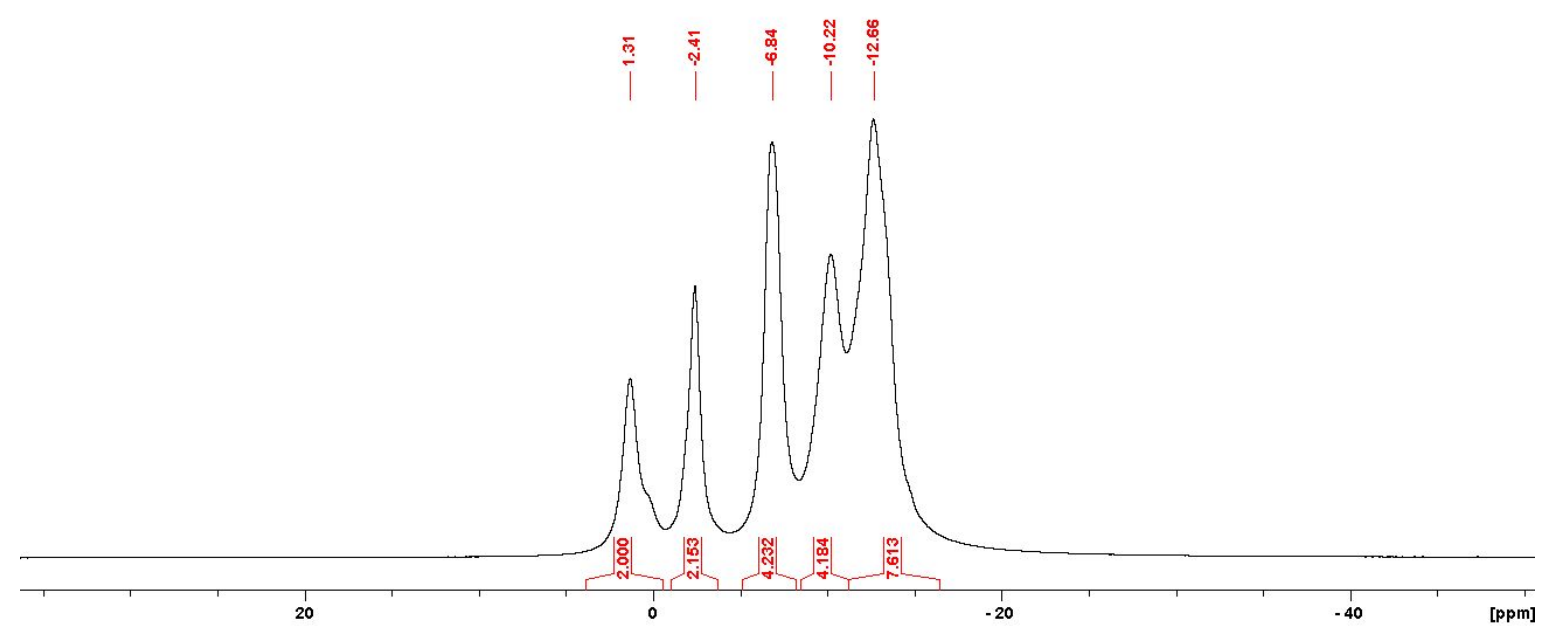

${ }^{31} \mathrm{P}\left\{{ }^{1} \mathrm{H}\right\}$ NMR spectrum of $4 \mathrm{Se}\left(\mathrm{CDCl}_{3}\right)$ :

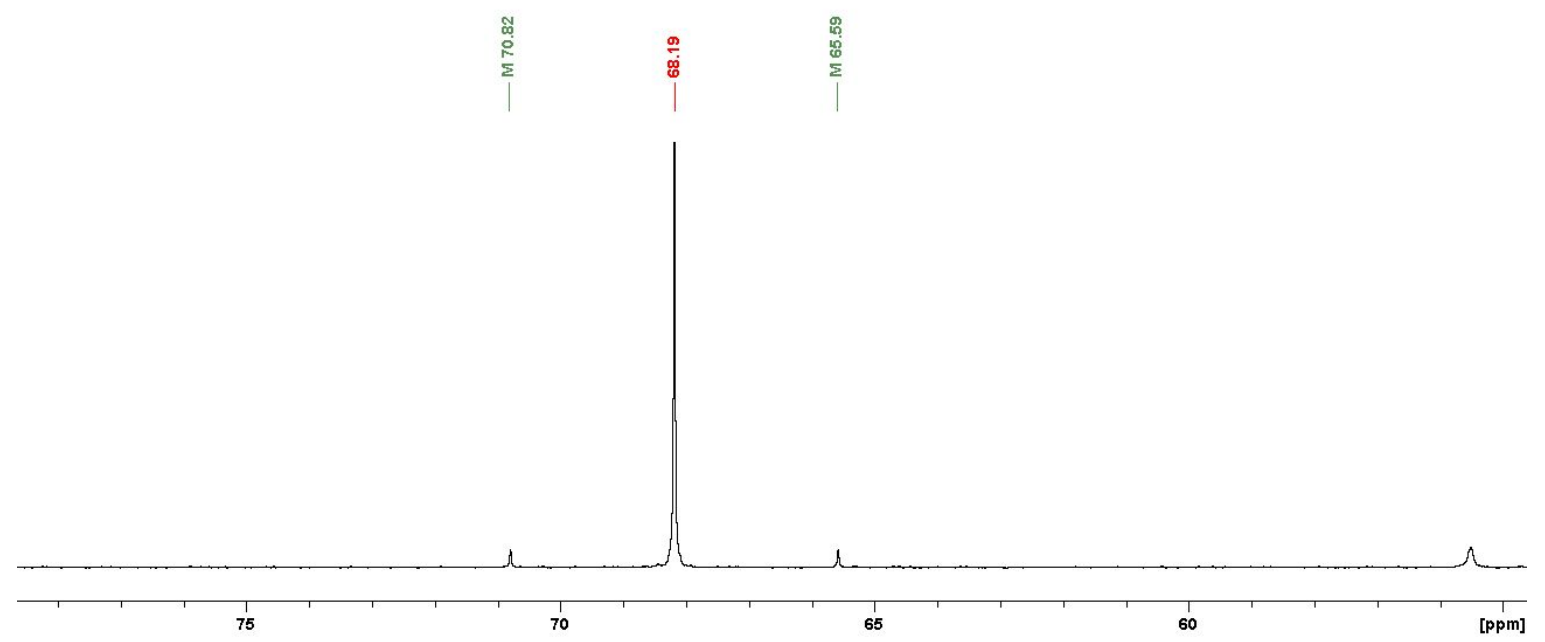


[1- $\left(1^{\prime}\right.$-closo- $\left.1^{\prime}, 7^{\prime}-\mathrm{C}_{2} \mathrm{~B}_{10} \mathrm{H}_{11}\right)-7-\mathrm{P}(\mathrm{Se}) \mathrm{Ph}_{2}$-closo-1,7- $\left.\mathrm{C}_{2} \mathrm{~B}_{10} \mathrm{H}_{10}\right]$ (1Se)

${ }^{1} \mathrm{H} \mathrm{NMR}\left(\mathrm{CDCl}_{3}\right)$ :

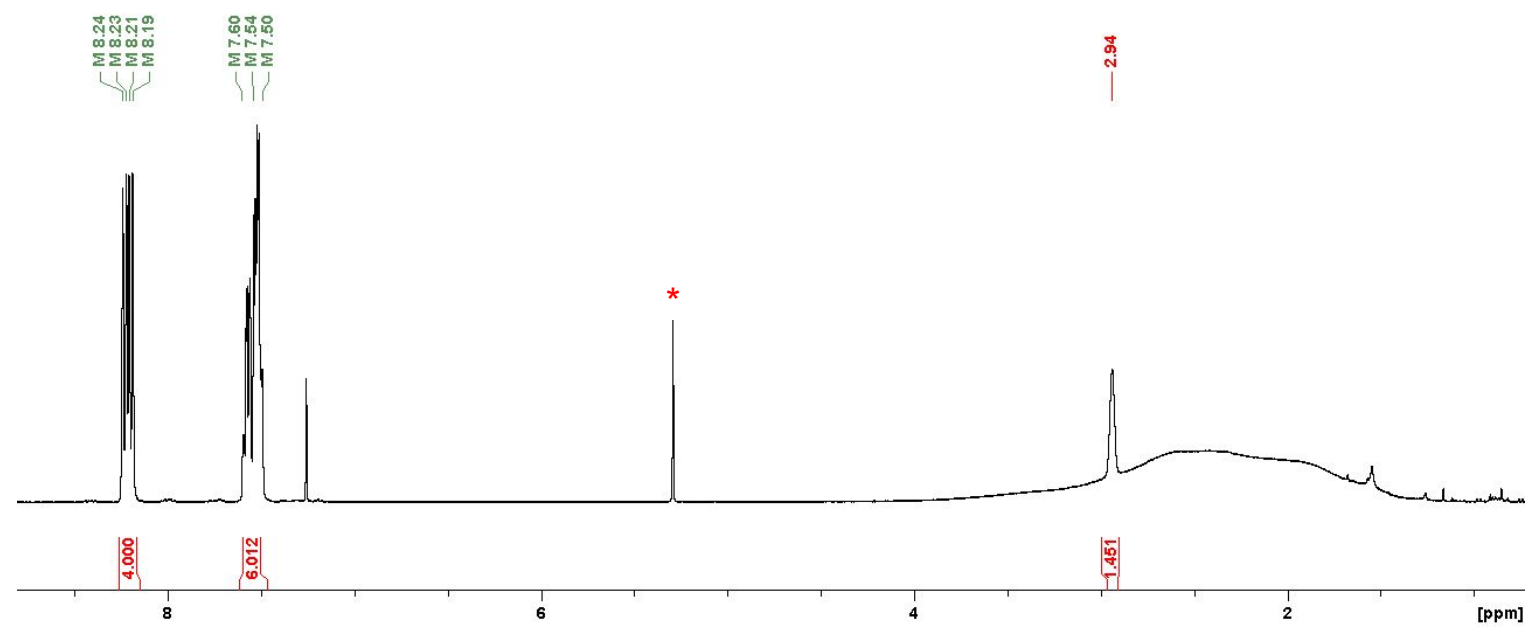

${ }^{11} \mathrm{~B}\left\{{ }^{1} \mathrm{H}\right\}$ NMR spectrum of $1 \mathrm{Se}\left(\mathrm{CDCl}_{3}\right)$ :

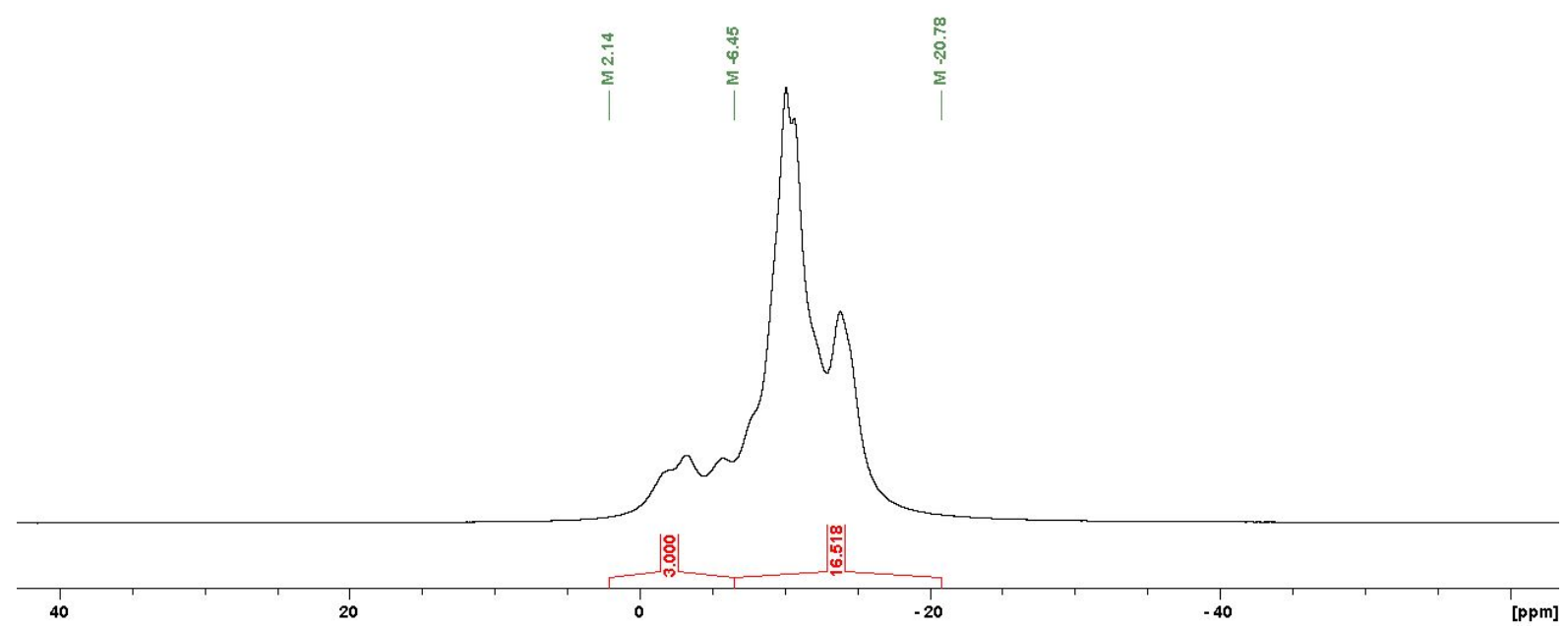


${ }^{31} \mathrm{P}\left\{{ }^{1} \mathrm{H}\right\}$ NMR spectrum of $1 \mathrm{Se}\left(\mathrm{CDCl}_{3}\right)$ :

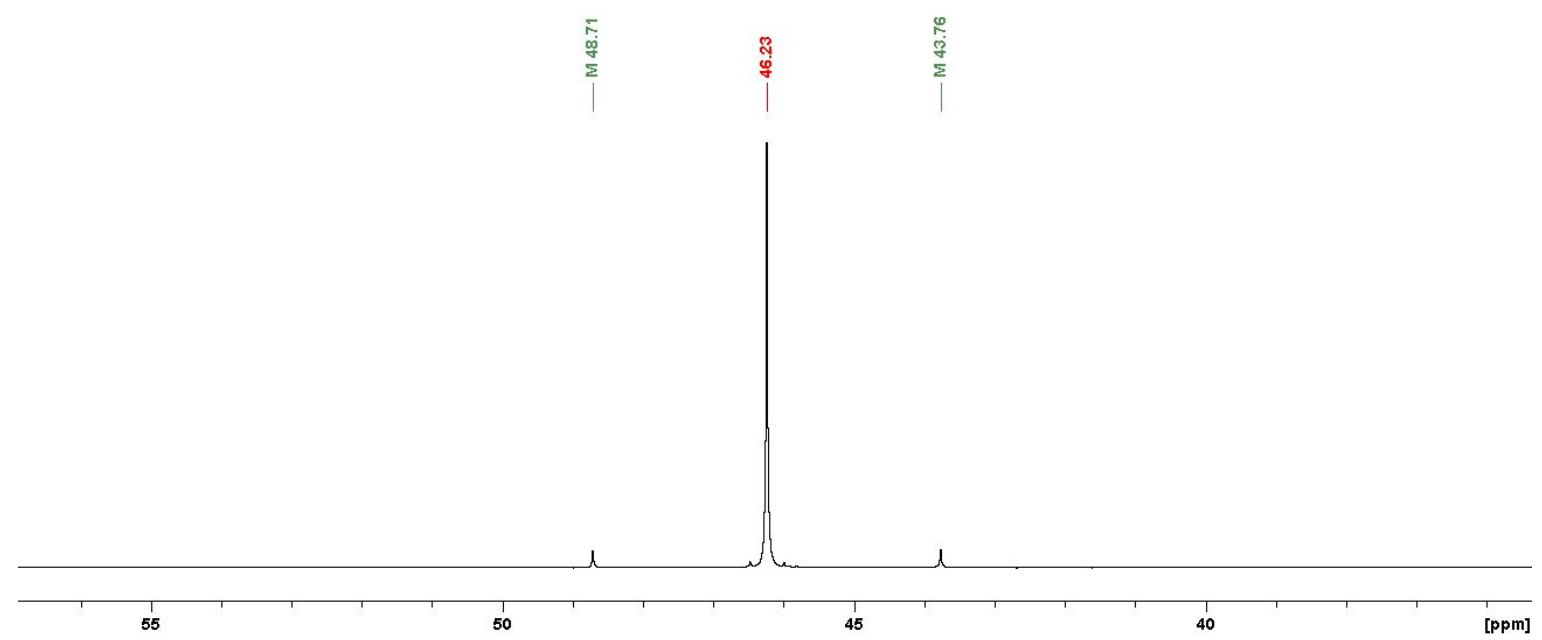

${ }^{77}$ Se NMR spectrum of $1 \mathrm{Se}\left(\mathrm{CDCl}_{3}\right)$ :

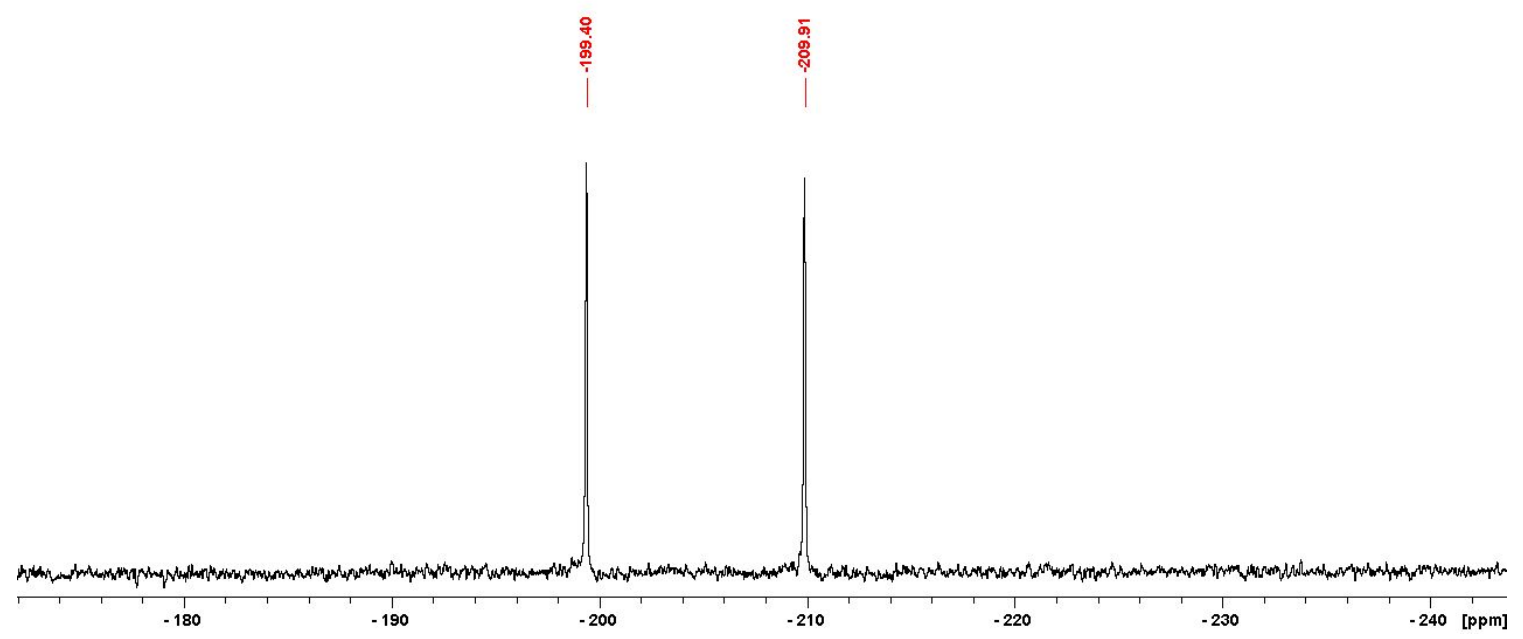


[1-P(Se)(H) ${ }^{t} \mathrm{Bu}-$ closo-1,2- $\left.\mathrm{C}_{2} \mathrm{~B}_{10} \mathrm{H}_{11}\right]$ (3Se)

${ }^{1} \mathrm{H} \mathrm{NMR}\left(\mathrm{CDCl}_{3}\right)$ :

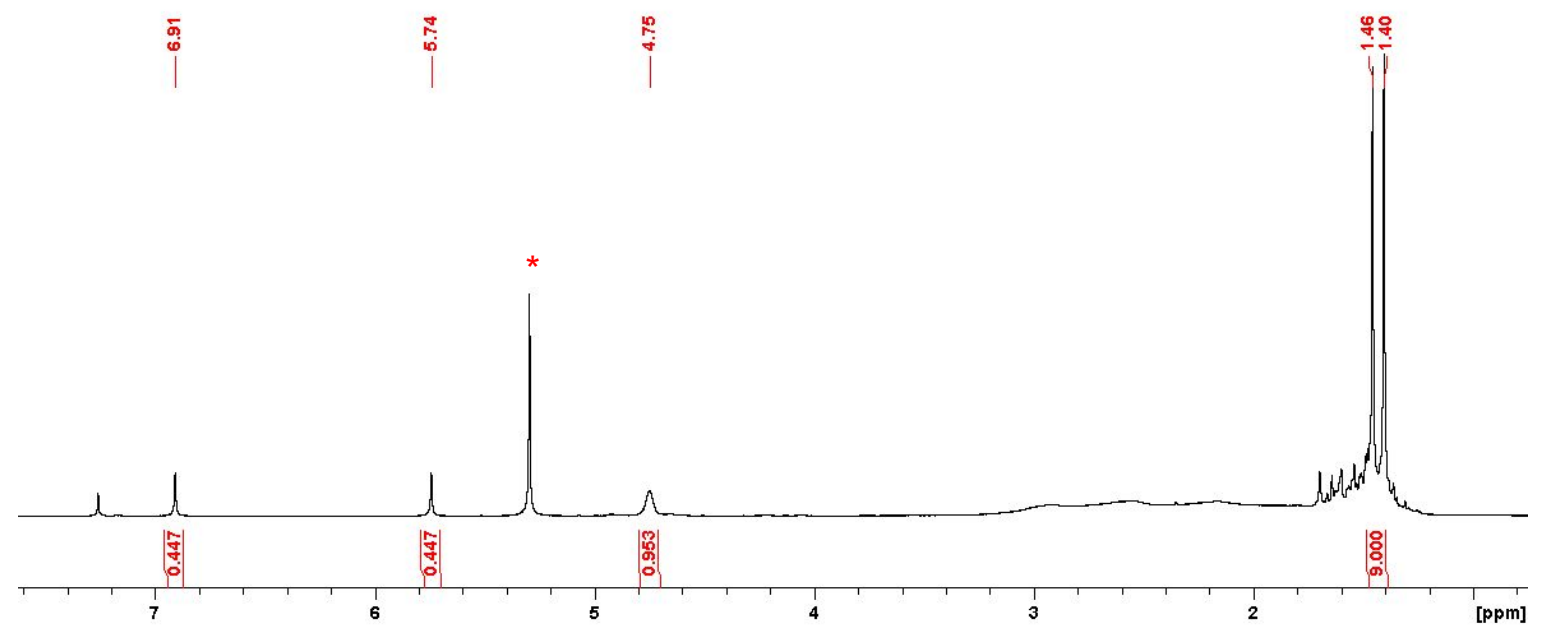

${ }^{11} \mathrm{~B}\left\{{ }^{1} \mathrm{H}\right\}$ NMR spectrum of $\mathbf{3 S e}\left(\mathrm{CDCl}_{3}\right)$ :
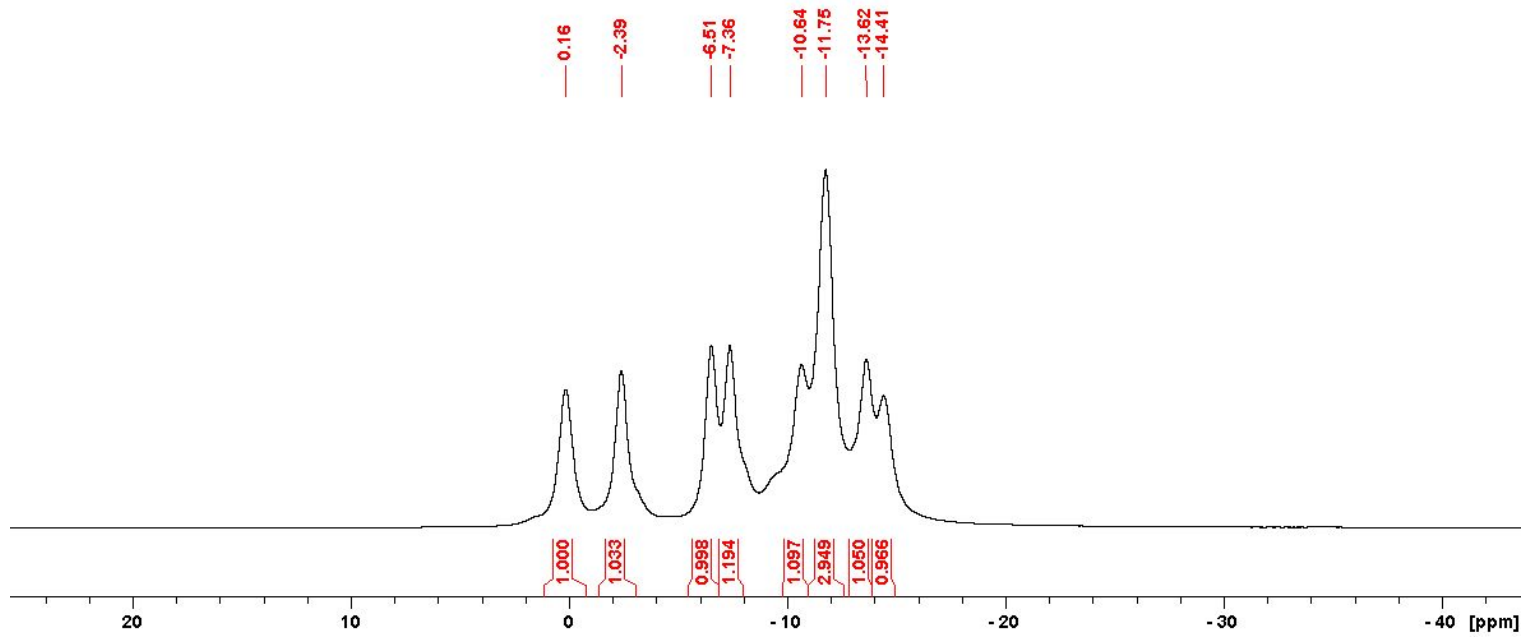
${ }^{31} \mathrm{P}\left\{{ }^{1} \mathrm{H}\right\}$ NMR spectrum of $\mathbf{3 S e}\left(\mathrm{CDCl}_{3}\right)$ :

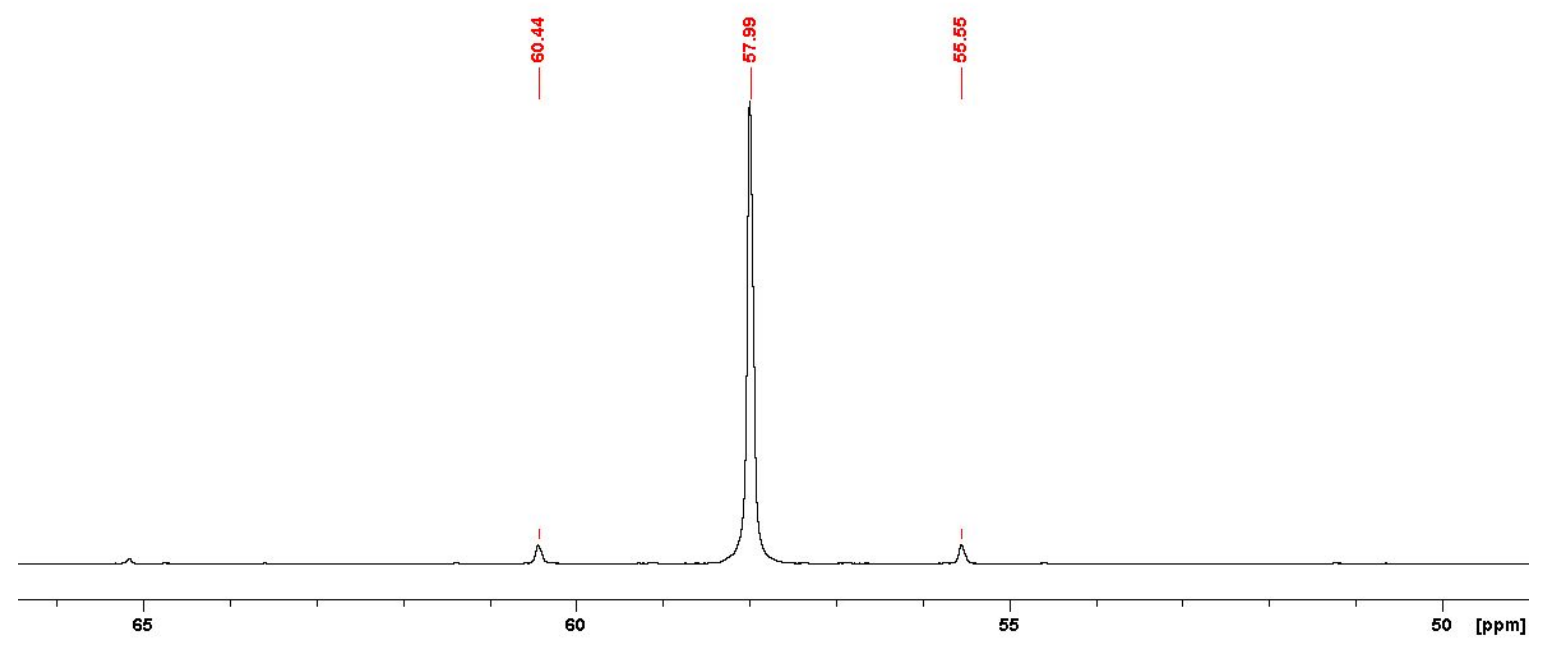

${ }^{31} \mathrm{P}$ NMR spectrum of $3 S e\left(\mathrm{CDCl}_{3}\right)$ :
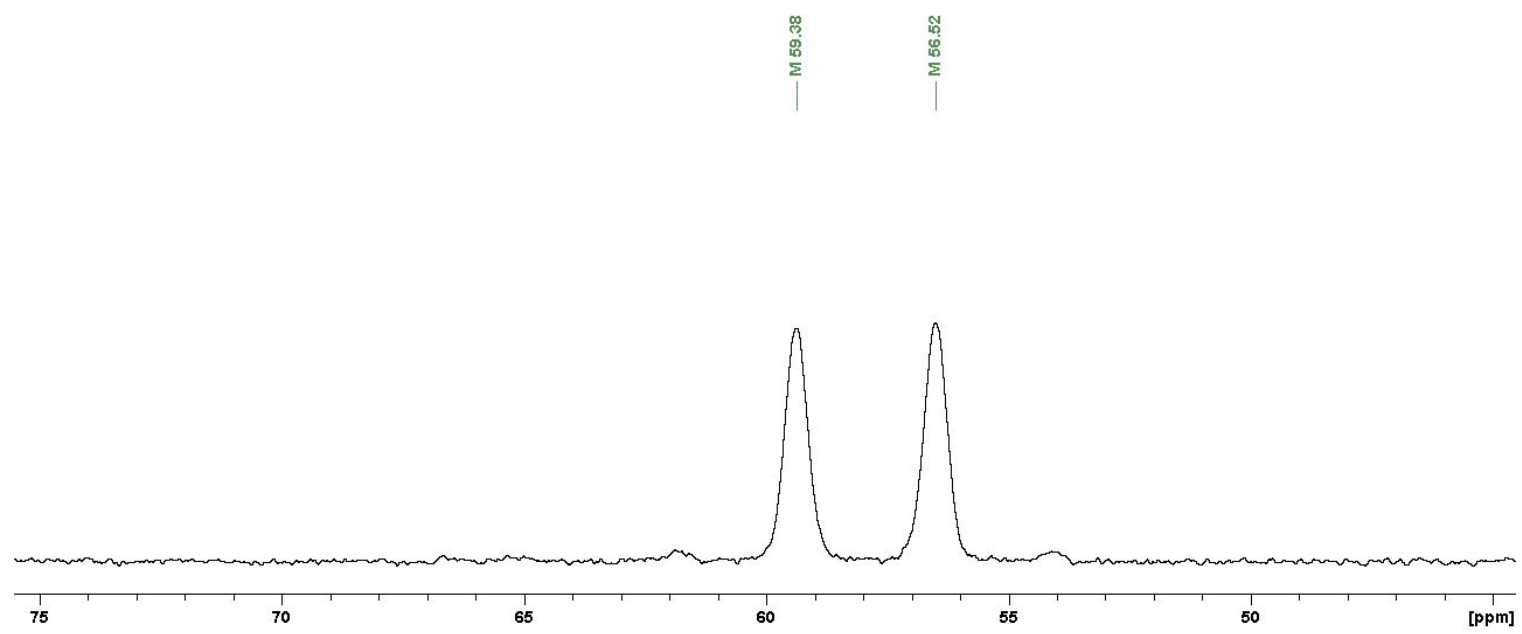
$\left[1-\mathrm{P}(\mathrm{Se})\left({ }^{\mathrm{t}} \mathrm{Bu}\right)_{2}-\right.$ closo-1,2- $\left.\mathrm{C}_{2} \mathrm{~B}_{10} \mathrm{H}_{11}\right]$ (VIIISe)

${ }^{1} \mathrm{H} \operatorname{NMR}\left(\mathrm{C}_{6} \mathrm{D}_{6}\right)$ :

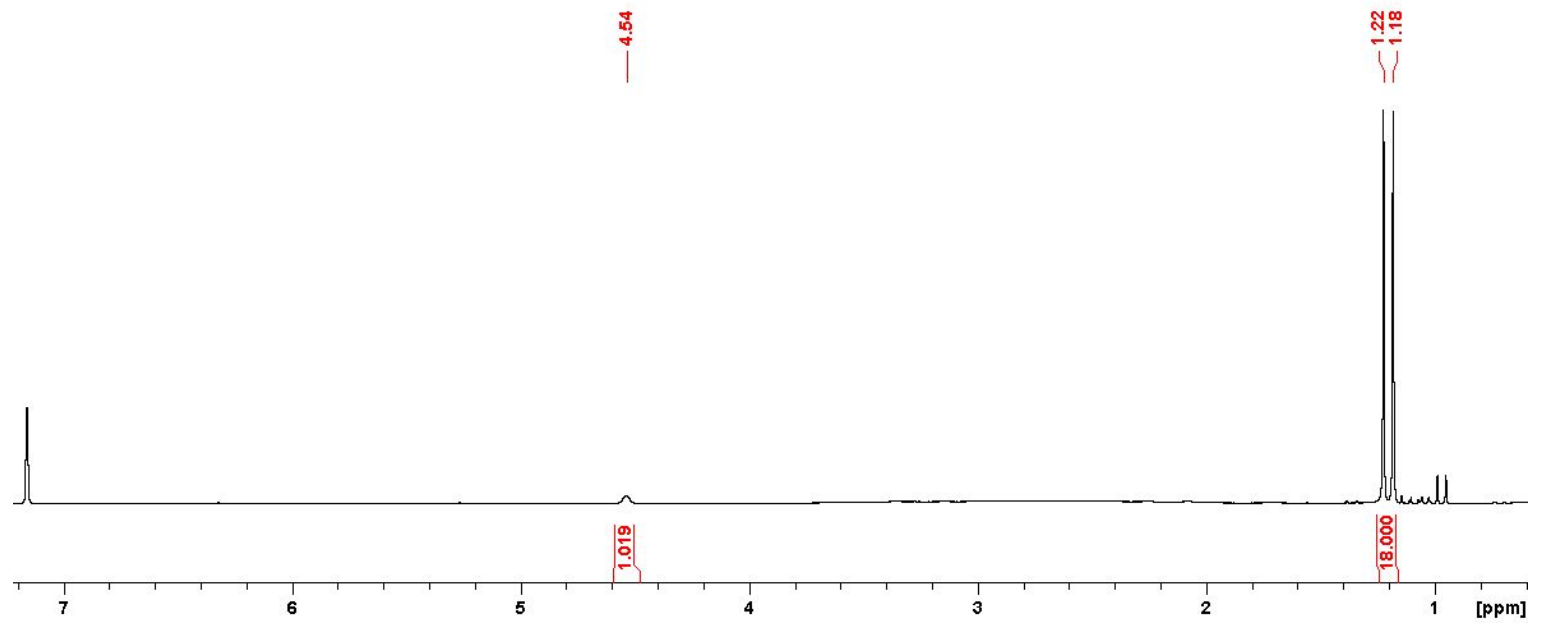

${ }^{11} B\left\{{ }^{1} H\right\}$ NMR spectrum of VIIISe $\left(C_{6} D_{6}\right)$ :

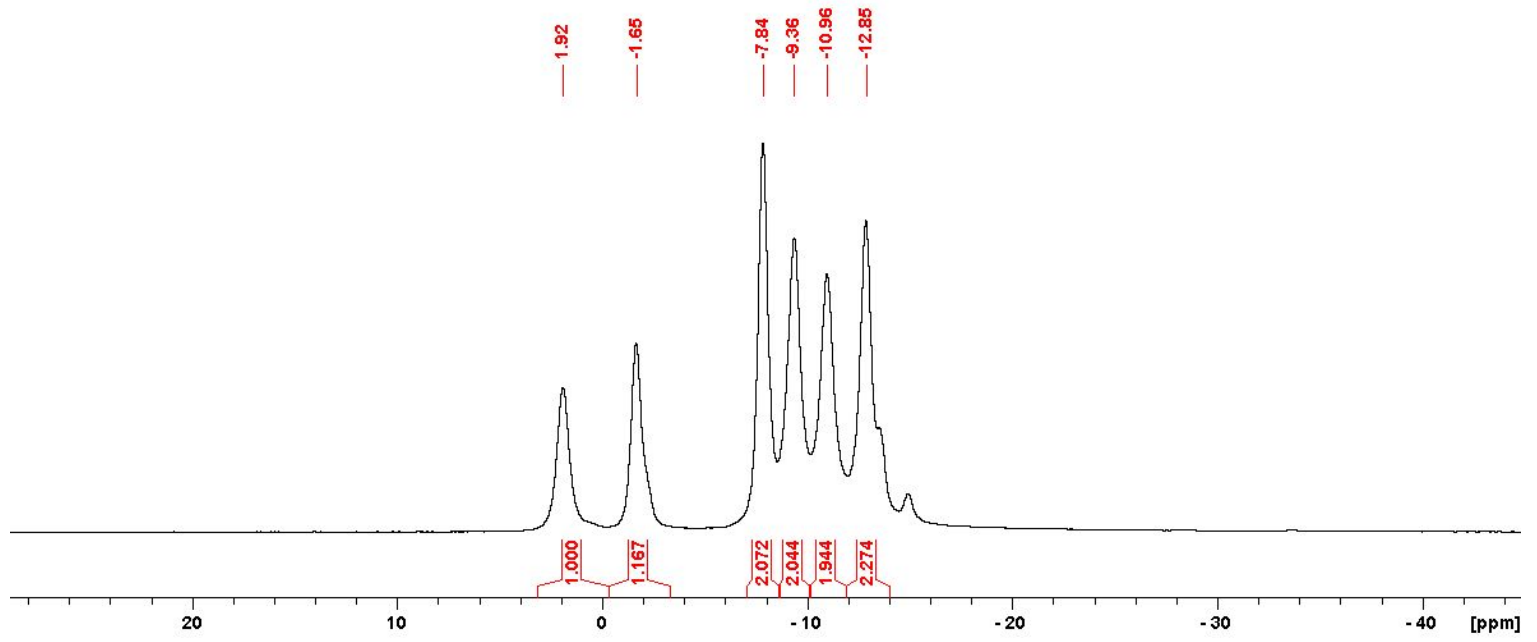


${ }^{31} \mathrm{P}\left\{{ }^{1} \mathrm{H}\right\}$ NMR spectrum of VIIISe $\left(\mathrm{C}_{6} \mathrm{D}_{6}\right)$ :

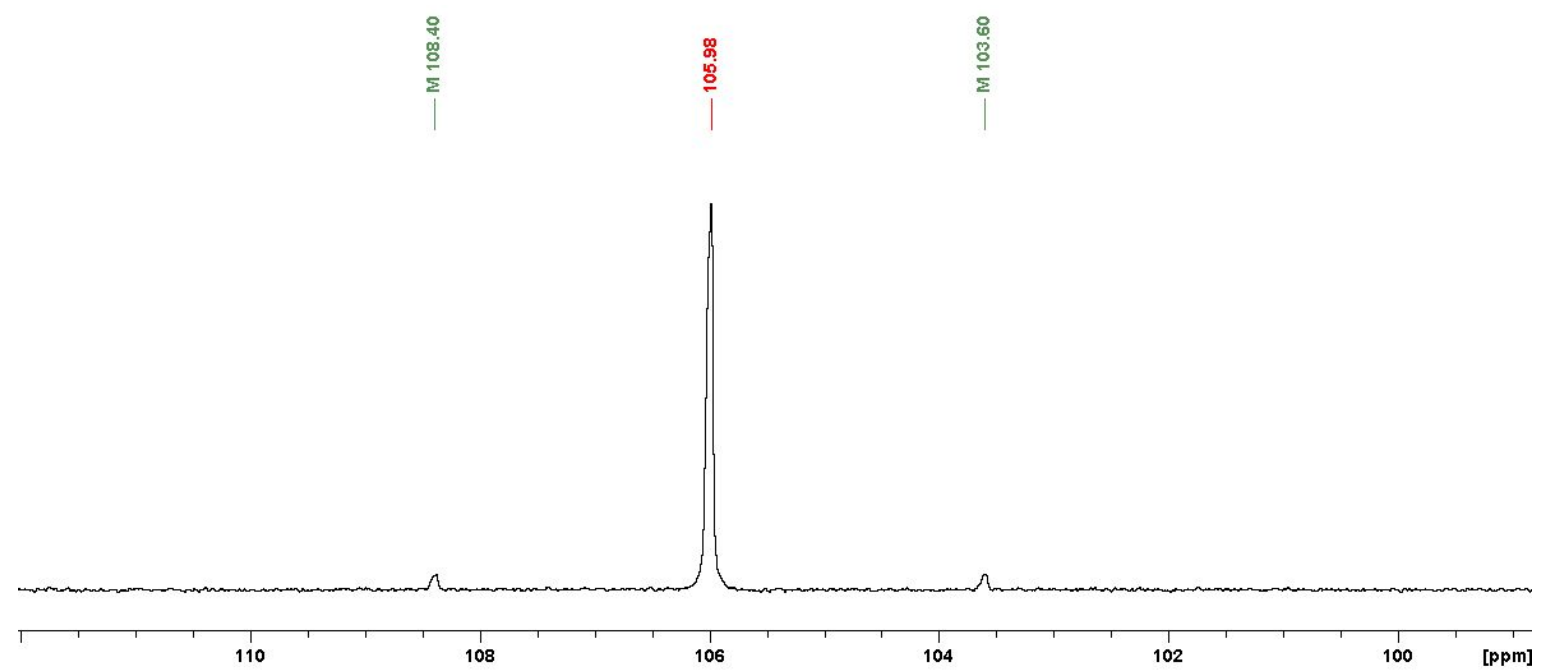

${ }^{77}$ Se NMR spectrum of VIIISe $\left(C_{6} D_{6}\right)$ :

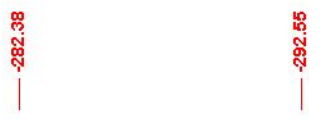

$\frac{1}{1}$ 
[BTMA][7-P(Se)Ph - -nido-7,8- $\left.\mathrm{C}_{2} \mathrm{~B}_{9} \mathrm{H}_{11}\right]$ ([BTMA]XSe)

${ }^{1} \mathrm{H}$ NMR $\left[\left(\mathrm{CD}_{3}\right)_{2} \mathrm{CO}\right]$ :

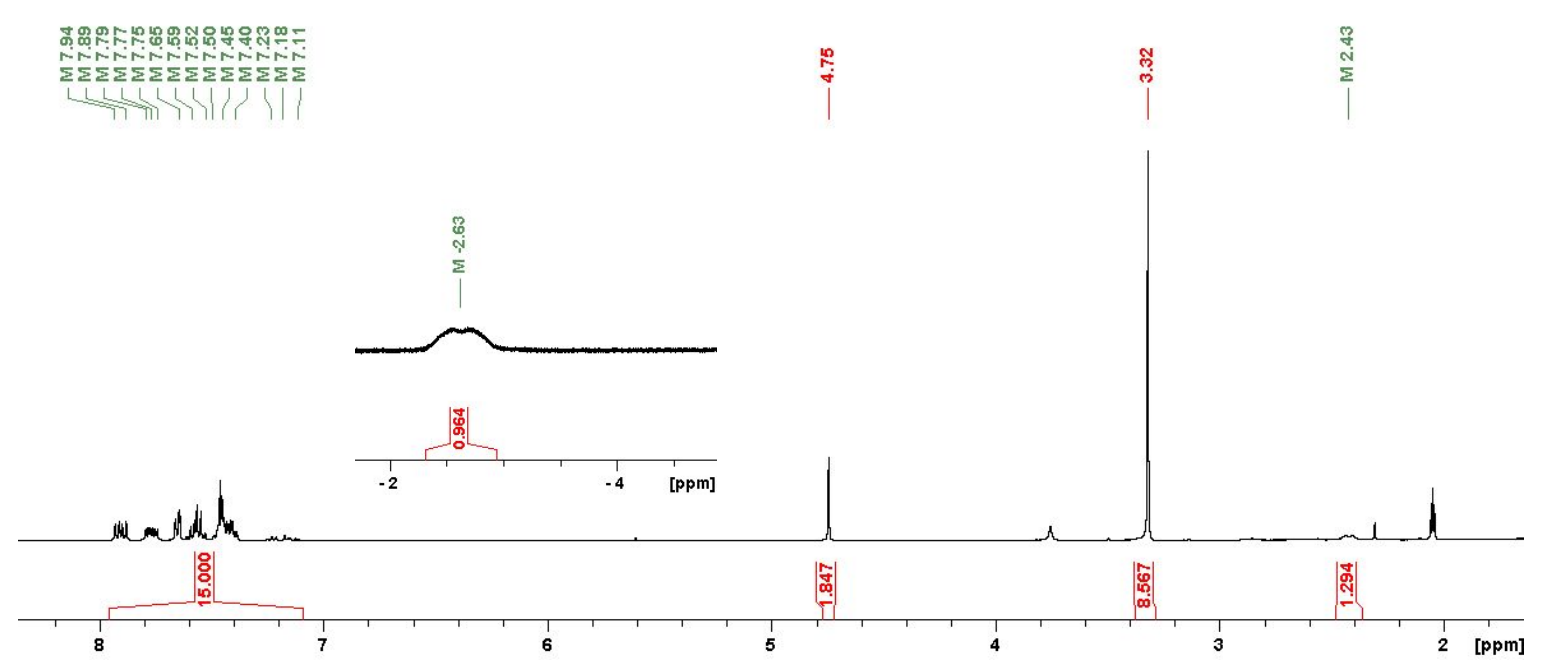

${ }^{11} \mathrm{~B}\left\{{ }^{1} \mathrm{H}\right\}$ NMR of [BTMA]XSe $\left[\left(\mathrm{CD}_{3}\right)_{2} \mathrm{CO}\right]$ :
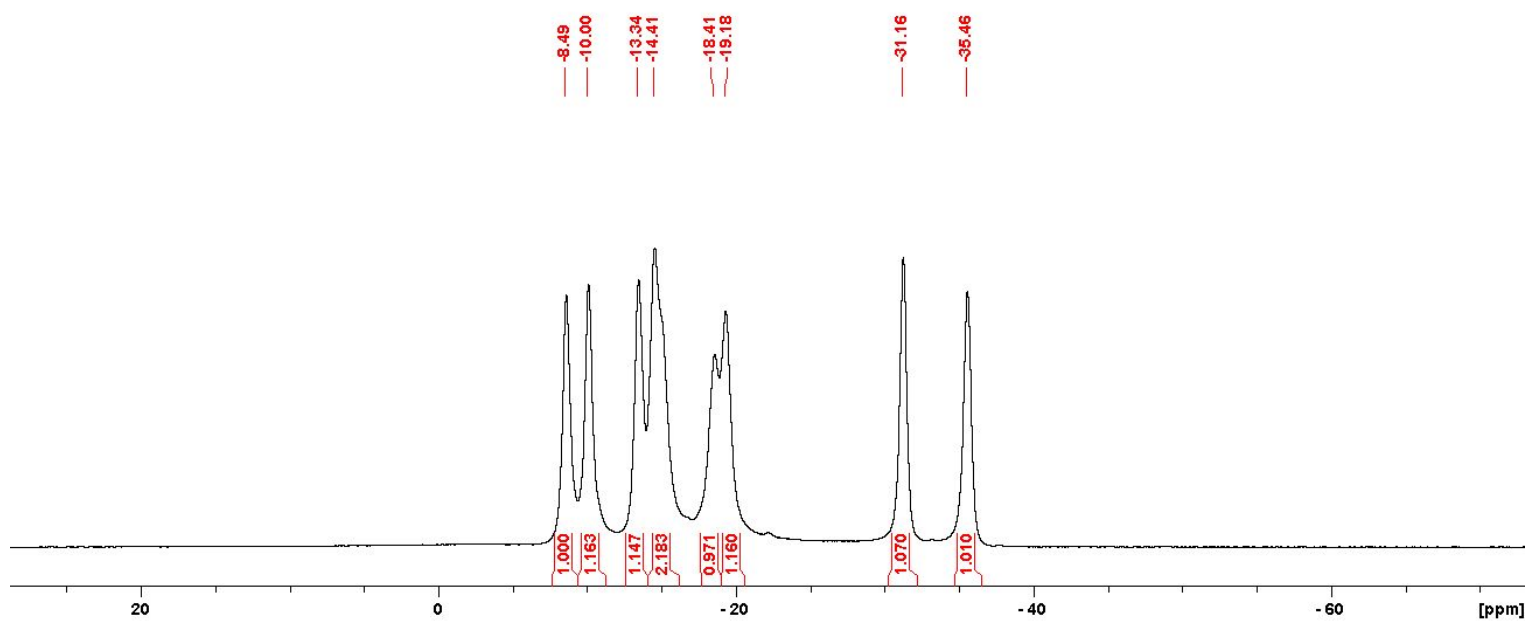
${ }^{31} \mathrm{P}\left\{{ }^{1} \mathrm{H}\right\}$ NMR spectrum of $[\mathrm{BTMA}] X \mathrm{Se}\left[\left(\mathrm{CD}_{3}\right)_{2} \mathrm{CO}\right]$ :

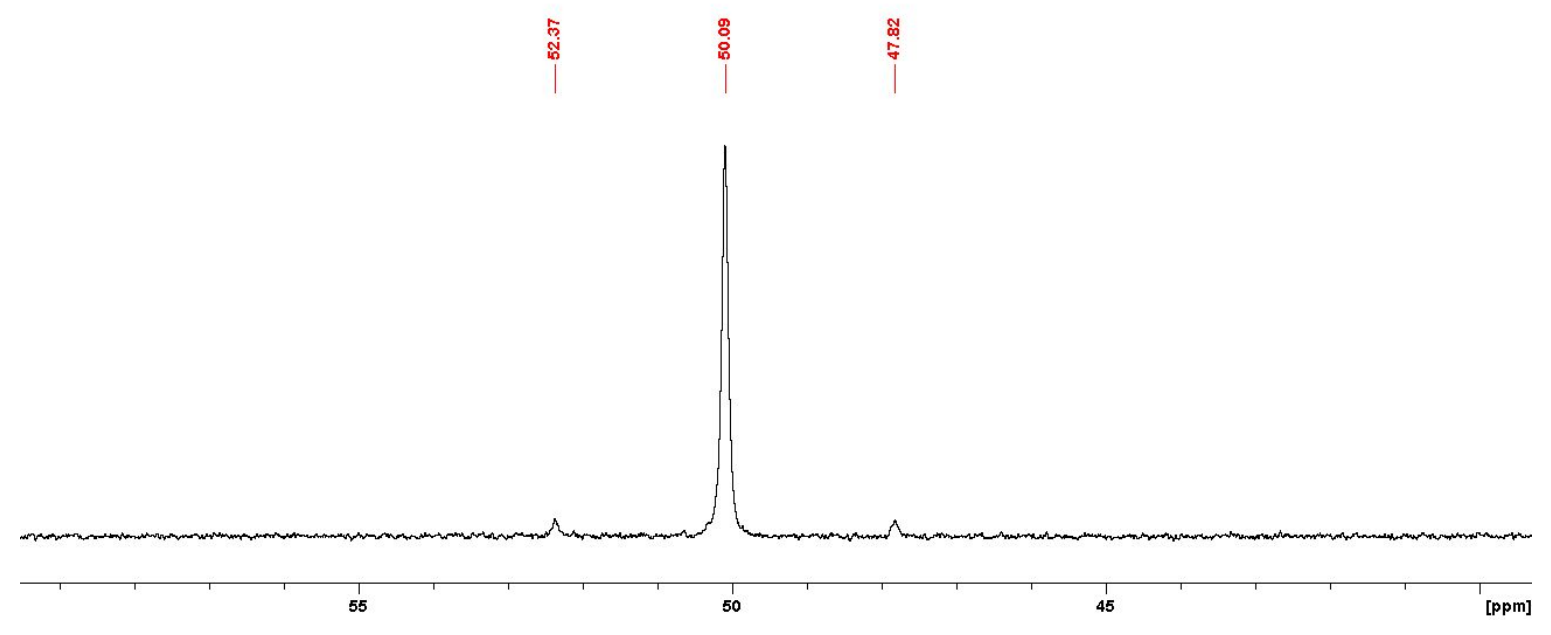

3 Computational Details

Proton affinity calculations used the Jaguar package ${ }^{1}$ and the standard Becke-Perdew (BP86) ${ }^{2}$ density functional. The 6-31G* basis set was used for all atoms, along with the polarisable continuum model (PCM) as implemented in Jaguar, using ethanol as the solvent. " ${ }^{3}$ "Loose" convergence (5 times larger than default criteria) was used for all geometry optimisations. Test calculations using the more stringent default convergence criteria did not lead to significant changes in energies, bond lengths, or angles, but were much more time-consuming. Apart from the use of the polarisable continuum model of solvation, this approach is in line with Bristol's Ligand Knowledge Bases (LKB-P) and the computational approach has been justified in that context. ${ }^{4}$ Calculations were performed on isolated molecules, and NBO atomic charges $^{5}$ were calculated for some ligands, as discussed below. Vibrational frequencies were not computed, and so the energetic data do not include a correction for zero-point energy, although we would expect this to be quite small. In the absence of frequency calculations, stationary points have not been verified as minima. However, these compounds are large and substituted with flexible alkyl and aryl groups, so optimisation to transition states seems unlikely for these carefully built, relatively low symmetry starting geometries.

PCM calculations allow for the consideration of solvation in DFT calculations by the inclusion of a dielectric continuum that implicitly models of the effect of (largely electrostatic) solvent-substrate effects. ${ }^{6}$ This is accomplished by the computation of electrostatic $\left(E_{e s}\right)$, dispersion-repulsion $\left(E_{d r}\right)$ and cavitation $\left(E_{c a v}\right)$ terms of the energy of solvation. ${ }^{7}$ The limitations of PCM calculations, and implicit solvent modelling in general, are that these models do not consider any variation in the density of solvent molecules around a molecule, meaning that they do not, for example, account for the energy associated with having a larger local solvent density around charged or electronegative atoms in a substrate. PCM calculations also only require the probe-radii and dielectric constant of a solvent, but this is by no means a perfect description 
of the space occupied by the solvent nor its structure and may lead to a miscalculation of the $E_{d r}$ and $E_{c a v}$ terms. That notwithstanding, in the present case the performance for the anionic nido carboranyl ligand $\mathbf{X}^{-}$is improved by the solvation model, as discussed below.

\subsection{Ph Rotation}

Manipulation of the calculated structure of XII in Jaguar's GUI Maestro confirms that Ph rotation results in close contacts (minimum distances of 0.90 and $0.72 \AA$ ) with a proton on each of the carborane cages. Space fill representation shows significant overlap between the phenyl protons and the protons present on the cage, suggesting that this is not a facile process and supporting the hypothesis that $\mathrm{Ph}$ rotation is restricted in XII.
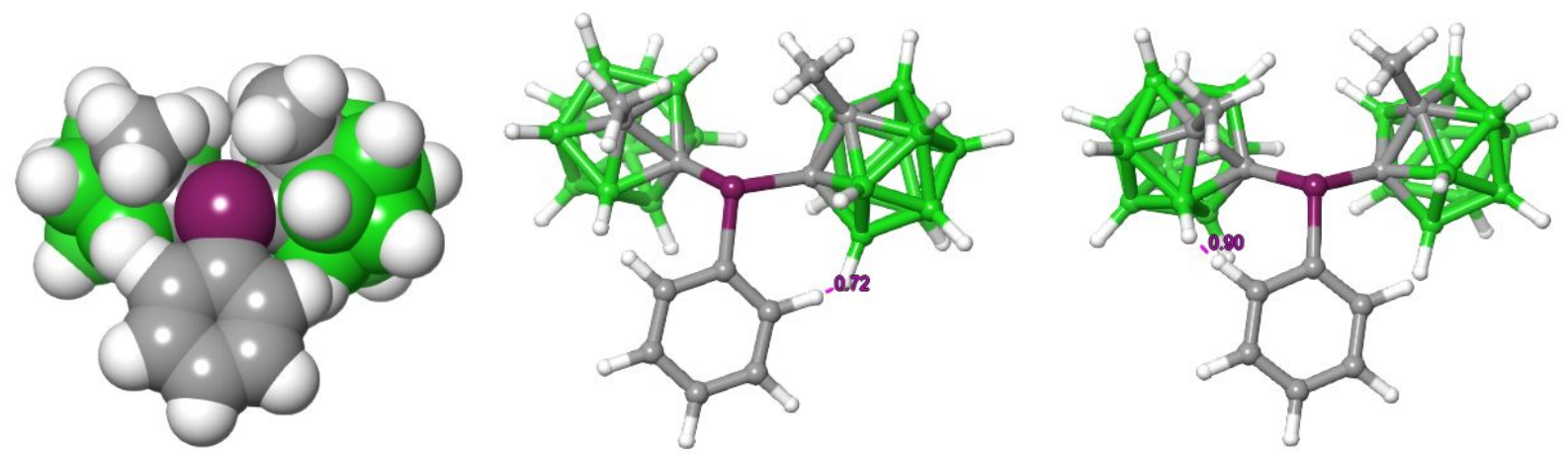

Figure S1: Close contacts on rotation of Ph, unoptimised geometry for visualisation.

\section{2 [7- $\mathrm{PPh}_{2}$-nido-7,8- $\left.\mathrm{C}_{2} \mathrm{~B}_{9} \mathrm{H}_{11}\right]^{-}\left(\mathbf{X}^{-}\right)$Calculations}

We initially followed the approached described in earlier work for LKB-P ${ }^{4}$ calculating PA data of isolated ligands, i.e. formally in the gas phase (denoted as $\mathrm{PA}_{\mathrm{gp}}$, Table S2 for full data). As shown in Figure S2, for neutral ligands the relationship was described quite well by a linear equation, giving a reasonably high regression coefficient $\left(R^{2}=0.6749\right)$. 


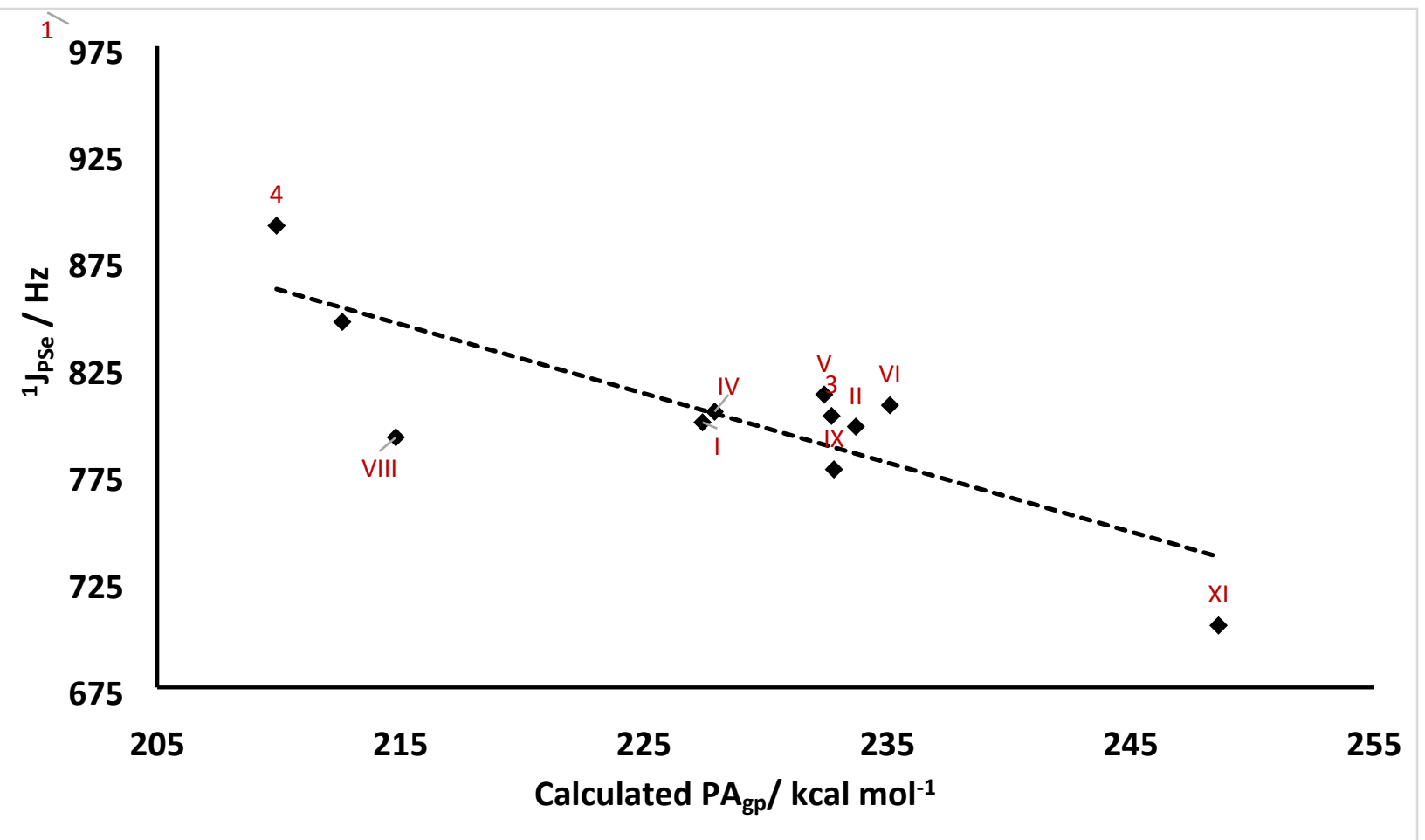

Figure S2: Plot of ${ }^{1} J_{\mathrm{PSe}}(\mathrm{Hz})$ versus calculated $\mathrm{PA}_{\mathrm{gp}}\left(\mathrm{kcal} \mathrm{mol}^{-1}\right)$ for the carboranylphosphine selenides and their parent carboranylphosphines.

However, when attempting to calculate a gas phase proton affinity for the anionic nido carborane $\mathbf{X}^{-}$, an unexpectedly high value of $308.1 \mathrm{kcal} \mathrm{mol}^{-1}$ was obtained (compared to ${ }^{1} \mathrm{JSe}_{\mathrm{PS}}=737 \mathrm{~Hz}$, which would lead to a predicted $\mathrm{PA}_{\mathrm{gp}}$ around $248 \mathrm{kcal} \mathrm{mol}^{-1}$ using the linear relationship established in Figure $\mathrm{S2}$, i.e. $\mathrm{PA}_{\mathrm{gp}}=$ $\left.\left.\left({ }^{1} J_{P S}-1540.6\right) /-3.2359\right)\right)$. The calculated $\mathrm{PA}_{\mathrm{gp}}$ value is likely to be so high because of to the charged nature of this ligand, making the gas phase protonation of an anion particularly favourable due to the overall neutralisation of ligand charge. Attempts to compensate for this by using a PCM solvation model (solvent=ethanol as described above) gave a lower PA, reducing the PA for $\mathbf{X}^{-}$by approximately $40 \mathrm{kcal}$ $\mathrm{mol}^{-1}$ (to $279.31 \mathrm{kcal} \mathrm{mol}^{-1}$ ). In our initial trial calculations, the PA of a range of neutral ligands in turn increased by $30-40 \mathrm{kcal} \mathrm{mol}^{-1}$, see Table $\mathrm{S} 2$ below, in the continuum dielectric medium, improving the description of the inverse relationship between ${ }^{1}{ }_{\text {PSe }}$ and PA with a linear equation (Figure S3).

Table S2: Comparison of gas phase and PCM calculated PA data $\left(\mathrm{kcal} \mathrm{mol}^{-1}\right)$ for a subset of ligands.

\begin{tabular}{|c|c|c|c|c|c|}
\hline Carboranylphosphine & $\begin{array}{c}{ }^{1} \mathrm{JPS}_{\mathrm{PSe}} \\
(\mathrm{Hz})\end{array}$ & $\mathrm{PA}_{\mathrm{gp}}$ & $\begin{array}{c}\mathrm{PA} \\
(\mathrm{PCM})\end{array}$ & $\begin{array}{c}\mathrm{E} \text { (Ligand, PCM, } \\
\text { Hartree })\end{array}$ & $\begin{array}{c}\mathrm{E}\left(\mathrm{H}^{+} \text {.Ligand, }\right. \\
\mathrm{PCM}, \text { Hartree })\end{array}$ \\
\hline $\mathbf{I V}$ & 804 & 227.9 & 265.0 & -1175.417736 & -1175.840104 \\
\hline $\mathbf{I X}$ & 704 & 248.6 & 280.3 & -1136.144579 & -1136.591189 \\
\hline $\mathbf{X}$ & 737 & 308.1 & 278.9 & -1111.359376 & -1111.805391 \\
\hline $\mathbf{X} \mathbf{}$ & 891 & 209.9 & 248.9 & -1234.690735 & -1235.087299 \\
\hline
\end{tabular}




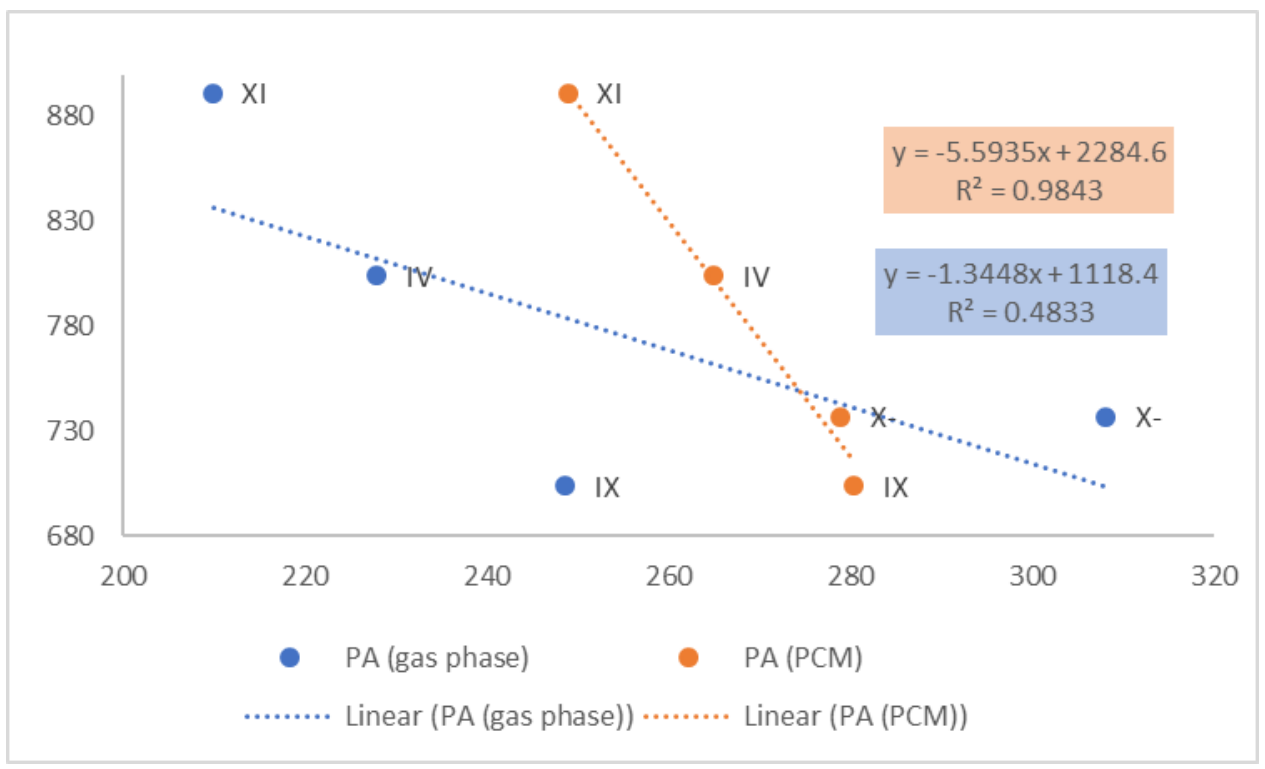

Figure S3: Comparison of gas phase and PCM calculated PA data for subset of ligands.

While the linear relationship between ${ }^{1} J_{\mathrm{PSe}}$ and PA is improved when the anionic ligand $\mathbf{X}^{-}$is included (Figure S3), there is an additional problem in this case, i.e. protonation of $\mathbf{X}^{-}$might not necessarily result in protonation at the phosphorus, but rather protonation on the open face of the carborane cage. This was supported by inspection of the HOMO for the ligand, shown below (Figure S4), which shows a relatively small lobe for the lone pair on $\mathrm{P}$, and significant orbital contributions on the cage, and appears energetically more favourable with the computational approach used here. Calculating the gas phase proton affinity of this alternative site for protonation, i.e. instead of the phosphorus, led to a calculated gas phase proton affinity of $306.7 \mathrm{kcal} \mathrm{mol}^{-1}$, which, while smaller, is still very high compared to the trend expected from ${ }^{1} \mathcal{J P S e}_{\mathrm{Pe}}$ data for this ligand.
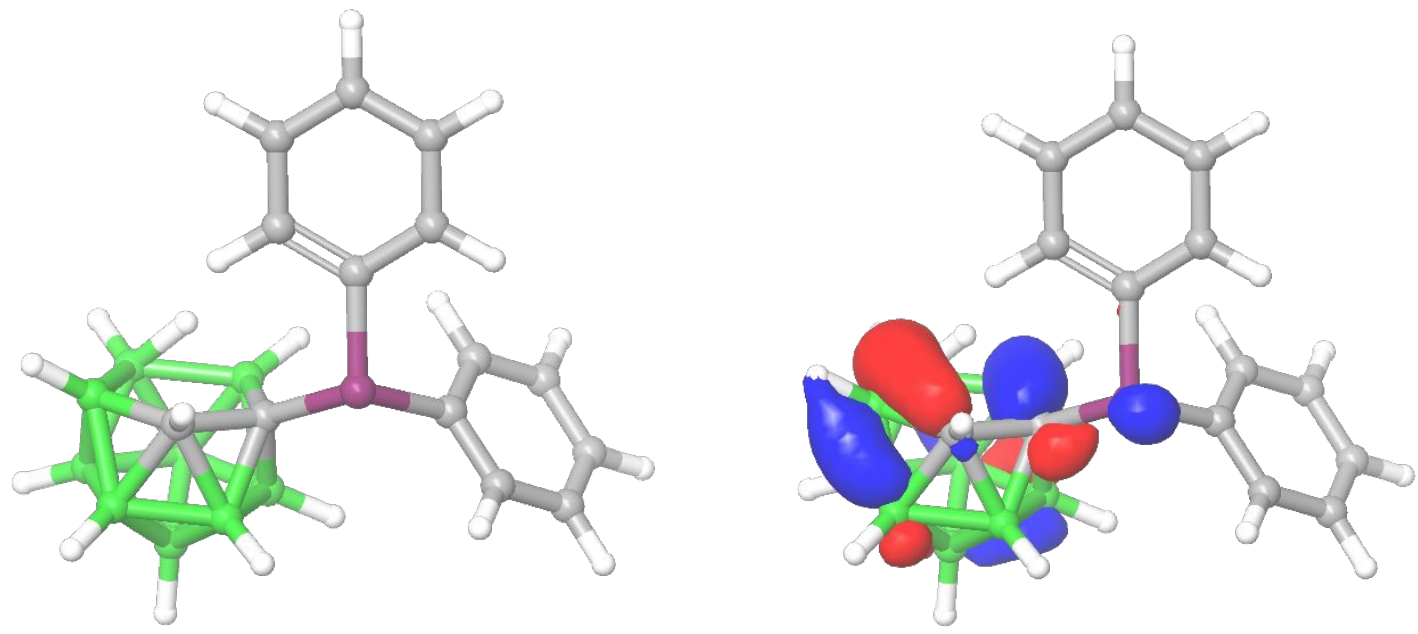

Figure S4: Optimised geometry and HOMO of $\mathbf{X}^{-}$. 


\subsection{Solvated Proton Affinity Calculations}

Solvated PA calculations were therefore completed for all ligands. A summary of the solvated PA calculation data is available in Table S3, while the full set of $\mathrm{PA}_{\mathrm{gp}}$ results are shown in Table S4.

Table S3: Summary of solution-phase calculated data.

\begin{tabular}{|c|c|c|c|c|}
\hline Carboranylphosphine & $\begin{array}{c}\text { Calculated Energy } \\
\text { of Free Ligand } \\
\text { (Hartrees) }\end{array}$ & $\begin{array}{l}\text { Calculated Energy } \\
\text { of Protonated } \\
\text { Ligand (Hartrees) }\end{array}$ & $\begin{array}{l}\text { Calculated Proton } \\
\text { Affinity }\left(\mathrm{kcal} \mathrm{mol}^{-1}\right)\end{array}$ & $\begin{array}{c}\text { HOMO } \\
\text { Energy }(\mathrm{eV})\end{array}$ \\
\hline $\mathbf{I}$ & -1136.106793 & -1136.529590 & 265.3 & -0.2207 \\
\hline II & -1136.127314 & -1136.556029 & 269.0 & -0.2154 \\
\hline III & -1136.130286 & -1136.561045 & 270.3 & -0.2136 \\
\hline IV & -1175.417736 & -1175.840104 & 265.0 & -0.2189 \\
\hline $\mathbf{V}$ & -1367.140042 & -1367.564936 & 266.6 & -0.2128 \\
\hline VI & -1940.144245 & -1940.567323 & 265.5 & -0.2022 \\
\hline VII & -1940.165663 & -1940.594159 & 268.9 & -0.2138 \\
\hline 1 & -1466.993874 & -1467.421645 & 268.4 & -0.2130 \\
\hline 2 & -2271.033201 & -2271.459080 & 267.2 & -0.2120 \\
\hline 3 & -831.259391 & -831.677898 & 262.6 & -0.2310 \\
\hline VIII & -988.477665 & -988.914352 & 274.0 & -0.2070 \\
\hline IX & -1136.144579 & -1136.591189 & 280.3 & -0.1904 \\
\hline$x$ & -1111.359376 & -1111.805391 & 279.9 & -0.1829 \\
\hline $\mathbf{X I}$ & -1234.690735 & -1235.087299 & 248.8 & -0.2422 \\
\hline XII & -1314.534251 & -1314.931652 & 249.4 & -0.2382 \\
\hline 4 & -1235.914536 & -1236.311164 & 248.9 & -0.2395 \\
\hline XIII & -1175.440484 & -1175.871795 & 270.7 & -0.2132 \\
\hline XIV & -1367.168290 & -1367.598429 & 269.9 & -0.2134 \\
\hline $\mathbf{X V}^{\mathbf{a}}$ & -1111.784263 & -1112.213843 & 269.6 & -0.2059 \\
\hline 3_Me ${ }^{\mathrm{a}}$ & -713.336696 & -713.753697 & 261.7 & -0.2374 \\
\hline 3_iPra & -791.953744 & -792.369216 & 260.7 & -0.2351 \\
\hline 3_Cy & -908.684739 & -909.098408 & 259.6 & -0.2351 \\
\hline VIII_Me ${ }^{a}$ & -752.655119 & -753.084452 & 269.4 & -0.2228 \\
\hline VIII_iPra & -909.874710 & -910.310535 & 273.5 & -0.2143 \\
\hline VIII_Cy & -1143.339805 & -1143.765970 & 267.4 & -0.2129 \\
\hline $\mathbf{X V I ^ { \mathrm { a } }}$ & -1123.071518 & -1123.526330 & 285.4 & -0.1845 \\
\hline XVII & -1334.491978 & -1334.865591 & 234.4 & -0.2703 \\
\hline $\mathrm{PPh}_{2}\left(\mathrm{C}_{6} \mathrm{~F}_{5}\right)$ & -1532.430469 & -1532.861404 & 270.4 & -0.2026 \\
\hline
\end{tabular}

a Species which are not yet known and for which only calculated data is reported. 
Table S4: Summary of gas-phase calculated data.

\begin{tabular}{|c|c|c|c|c|}
\hline Carboranylphosphine & $\begin{array}{c}\text { Calculated } \\
\text { Energy of Free } \\
\text { Ligand (Hartrees) }\end{array}$ & $\begin{array}{c}\text { Calculated } \\
\text { Energy of } \\
\text { Protonated } \\
\text { Ligand (Hartrees) }\end{array}$ & $\begin{array}{l}\text { Calculated Proton } \\
\text { Affinity }\left(\mathrm{kcal} \mathrm{mol}^{-1}\right)\end{array}$ & $\begin{array}{l}\text { HOMO Energy } \\
(\mathrm{eV})\end{array}$ \\
\hline I & -1136.095093 & -1136.457513 & 227.4 & -0.2194 \\
\hline II & -1136.115263 & -1136.487686 & 233.7 & -0.2094 \\
\hline III & -1136.119318 & -1136.495315 & 235.9 & -0.2078 \\
\hline IV & -1175.405641 & -1175.768741 & 227.9 & -0.216 \\
\hline $\mathbf{V}$ & -1367.126045 & -1367.496334 & 232.4 & -0.2097 \\
\hline $\mathbf{V I}$ & -1940.127449 & -1940.502153 & 235.1 & -0.1944 \\
\hline VII & -1940.148379 & -1940.528088 & 238.3 & -0.2045 \\
\hline 1 & -1466.982755 & -1467.353638 & 232.7 & -0.2098 \\
\hline 2 & -2271.015811 & -2271.390244 & 235.0 & -0.2053 \\
\hline 3 & -831.2512739 & -831.593508 & 214.8 & -0.2347 \\
\hline VIII & -988.469032 & -988.840088 & 232.8 & -0.2078 \\
\hline IX & -1136.129982 & -1136.52611 & 248.6 & -0.1779 \\
\hline $\mathbf{X}^{-}$ & -1111.284312 & -1111.77527 & $\begin{array}{c}\text { (308.1, } \\
\text { discussed above) }\end{array}$ & -0.0585 \\
\hline $\mathbf{X I}$ & -1234.683533 & -1235.018098 & 209.9 & -0.2462 \\
\hline XII & -1314.521585 & -1314.861745 & 213.5 & -0.2434 \\
\hline 4 & -1235.901047 & -1236.239914 & 212.6 & -0.2494 \\
\hline $\mathbf{X V} \mathbf{V}^{\mathbf{a}}$ & -1111.773022 & -1112.144336 & 233.0 & -0.2036 \\
\hline 3_Me $\mathrm{Me}^{\mathrm{a}}$ & -713.3283298 & -713.6568049 & 206.1 & -0.2460 \\
\hline 3_iPra & -791.9460544 & -792.2821731 & 210.9 & -0.2404 \\
\hline 3_Cy & -908.6773775 & -909.0178933 & 213.7 & -0.2377 \\
\hline VIII_Me ${ }^{a}$ & -752.6463256 & -752.9931574 & 217.6 & -0.2293 \\
\hline VIII_iPra & -909.8662583 & -910.233427 & 230.4 & -0.2161 \\
\hline VIII_Cy ${ }^{a}$ & -1143.332125 & -1143.697824 & 229.5 & -0.2113 \\
\hline XVII ${ }^{a}$ & -1334.485548 & -1334.795896 & 194.8 & -0.2750 \\
\hline
\end{tabular}

a Species which are not yet known and for which only calculated data is reported.

Comparison of the two datasets in Figure $\mathbf{S} 5$ shows that the global model (including the anionic ligand $\mathbf{X}^{-}$) is significantly improved with the use of PCM calculations $\left(R^{2}=0.86\right.$ vs $R^{2}=0.47$ for the gas phase calculated proton affinities). Residual analysis of the regression equations (in Figure S6) reveals a more complicated picture, suggesting that while the cluster of ligands with ${ }^{1} J_{\text {Pse }}$ values between 780 and $800 \mathrm{~Hz}$ is described well by both models, those of more extreme basicity are captured a little better for solvated PA data, albeit with relatively large residuals (Figure S6, Table S5). It is also worth noting that the solvated $\mathrm{PA}$ data loses some of the finer resolution seen for $\mathrm{PA}_{\mathrm{gp}}$, considering, for example, $\mathbf{4}$ and $\mathbf{X I}$, as well as the alkyl-substituted variants of $\mathbf{3}$ and VIII. 


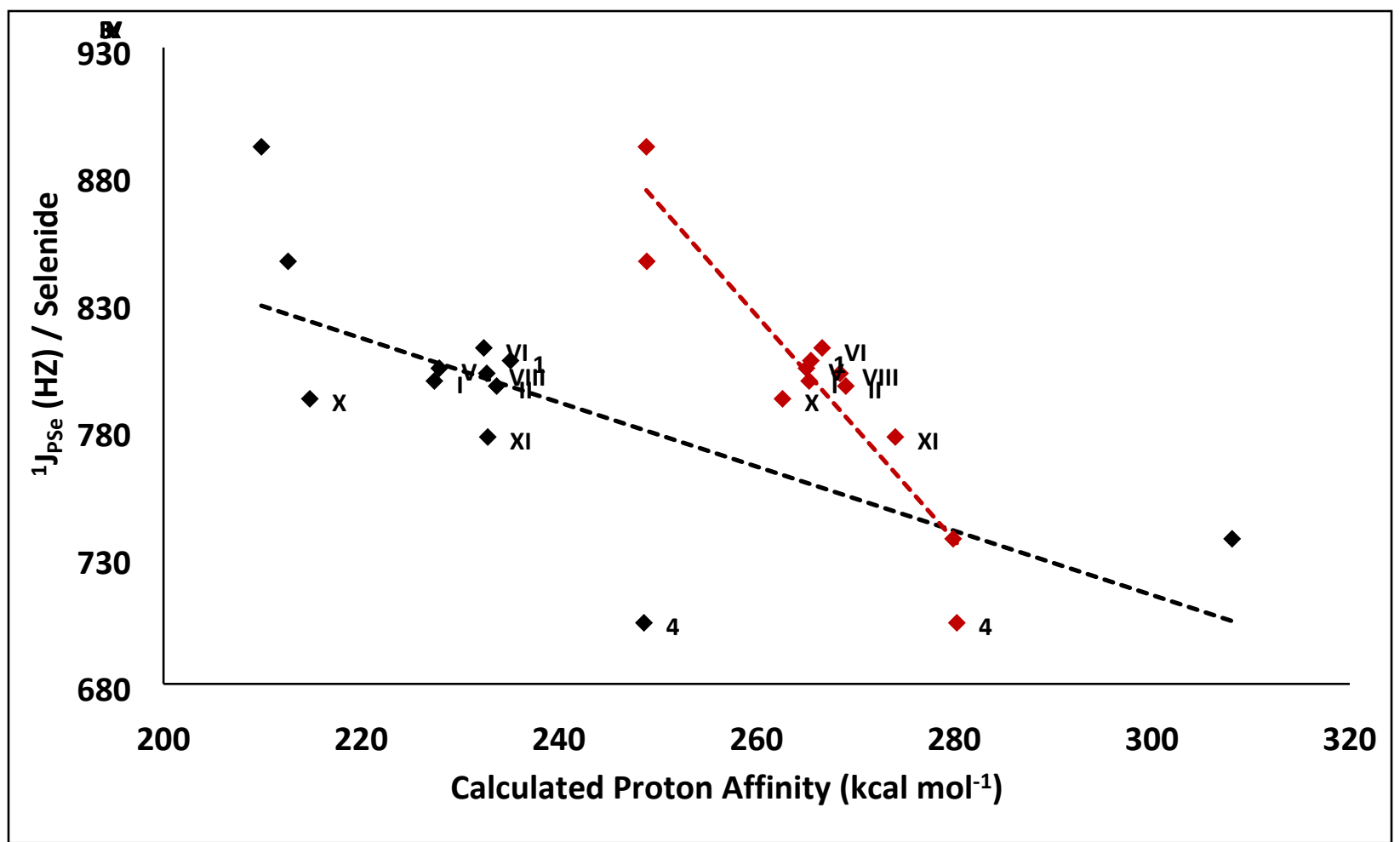

Figure S5: Calculated proton affinities $\left(\mathrm{kcal} \mathrm{mol}^{-1}\right)$ and ${ }^{1} J_{\mathrm{PSe}}(\mathrm{Hz})$ values for both gas phase (black) and solution phase (red) calculated proton affinities for a series of carboranylphosphines.

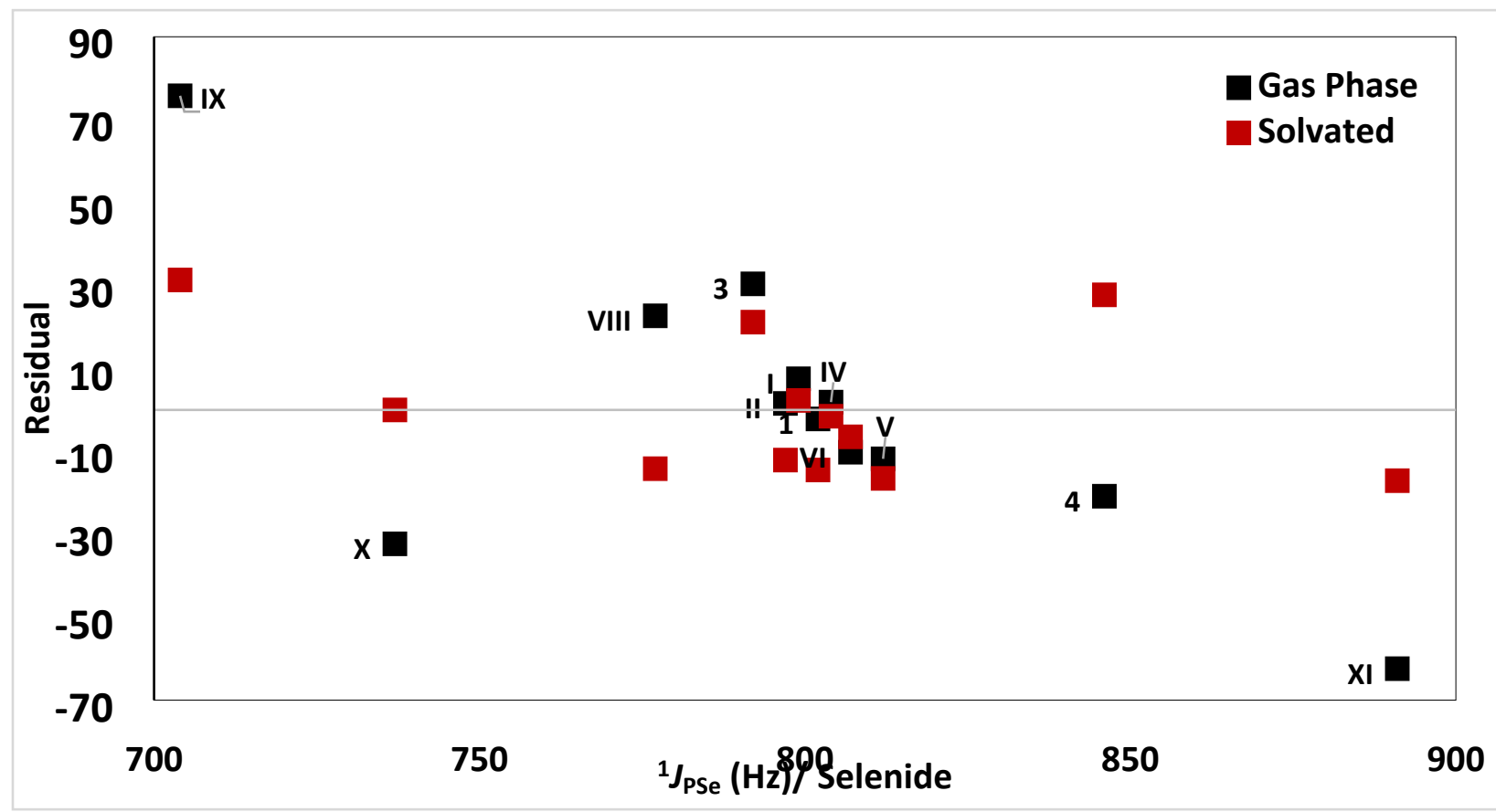

Figure S6: Residuals for the predicted values from the regression models for both the gas-phase and solvated proton affinities for a series of carboranylphosphines. 
Table S5: Experimental, predicted and residual values for ${ }^{1} J_{\mathrm{PSe}}(\mathrm{Hz})$ values for gas phase and solvated phase models for a series of carboranylphosphines.

\begin{tabular}{|c|c|c|c|c|c|}
\hline Carboranylphosphine & $\begin{array}{l}{ }^{1} J_{\mathrm{PSe}}(\mathrm{Hz}) / \\
\text { Selenide }\end{array}$ & $\begin{array}{c}\text { Gas Phase Model } \\
\text { Prediction of }{ }^{1} J_{\mathrm{PSe}} \\
(\mathrm{Hz})\end{array}$ & $\begin{array}{l}\text { Residual } \\
(\mathrm{gp}, \mathrm{Hz})\end{array}$ & $\begin{array}{c}\text { Solvated Phase } \\
\text { Model Prediction } \\
\text { of }^{1} J_{\text {PSe }}(\mathrm{Hz})\end{array}$ & $\begin{array}{c}\text { Residual } \\
\text { (PCM, } \\
\mathrm{Hz})\end{array}$ \\
\hline $\mathbf{I}$ & 799 & 806.5 & 7.5 & 801.3 & 2.3 \\
\hline II & 797 & 798.6 & 1.6 & 784.9 & -12.1 \\
\hline IV & 804 & 805.9 & 1.9 & 802.5 & -1.5 \\
\hline $\mathbf{V}$ & 812 & 800.2 & -11.8 & 795.5 & -16.5 \\
\hline VI & 807 & 796.8 & -10.2 & 800.5 & -6.5 \\
\hline 1 & 802 & 799.8 & -2.2 & 787.5 & -14.5 \\
\hline 3 & 792 & 822.4 & 30.4 & 813.2 & 21.2 \\
\hline VIII & 777 & 799.7 & 22.7 & 762.8 & -14.2 \\
\hline IX & 704 & 779.8 & 75.8 & 735.3 & 31.3 \\
\hline$x^{-}$ & 737 & 704.7 & -32.3 & 737.0 & 0.0 \\
\hline $\mathbf{X I}$ & 891 & 828.6 & -62.4 & 873.9 & -17.1 \\
\hline 4 & 846 & 825.2 & -20.8 & 873.8 & 27.8 \\
\hline
\end{tabular}

Past computational studies of $\mathrm{PA}_{\mathrm{gp}}$ have shown high correlation with the energy of the $\mathrm{HOMO}, 4,8$ which tends to be localised on the phosphorus lone pair for many monodentate P-donor ligands. Interestingly, the regression coefficient is higher for this linear relationship when the gas phase data are considered than for those calculated with PCM solvation (Figures S7 and S8), with slightly different subsets of ligands appearing as (mild) outliers. With a view to quantifying the basicity of both neutral and anionic carboranylphosphine ligands into context in the present study, we have focussed our discussion on the solvated PA data in the main body of this work. 


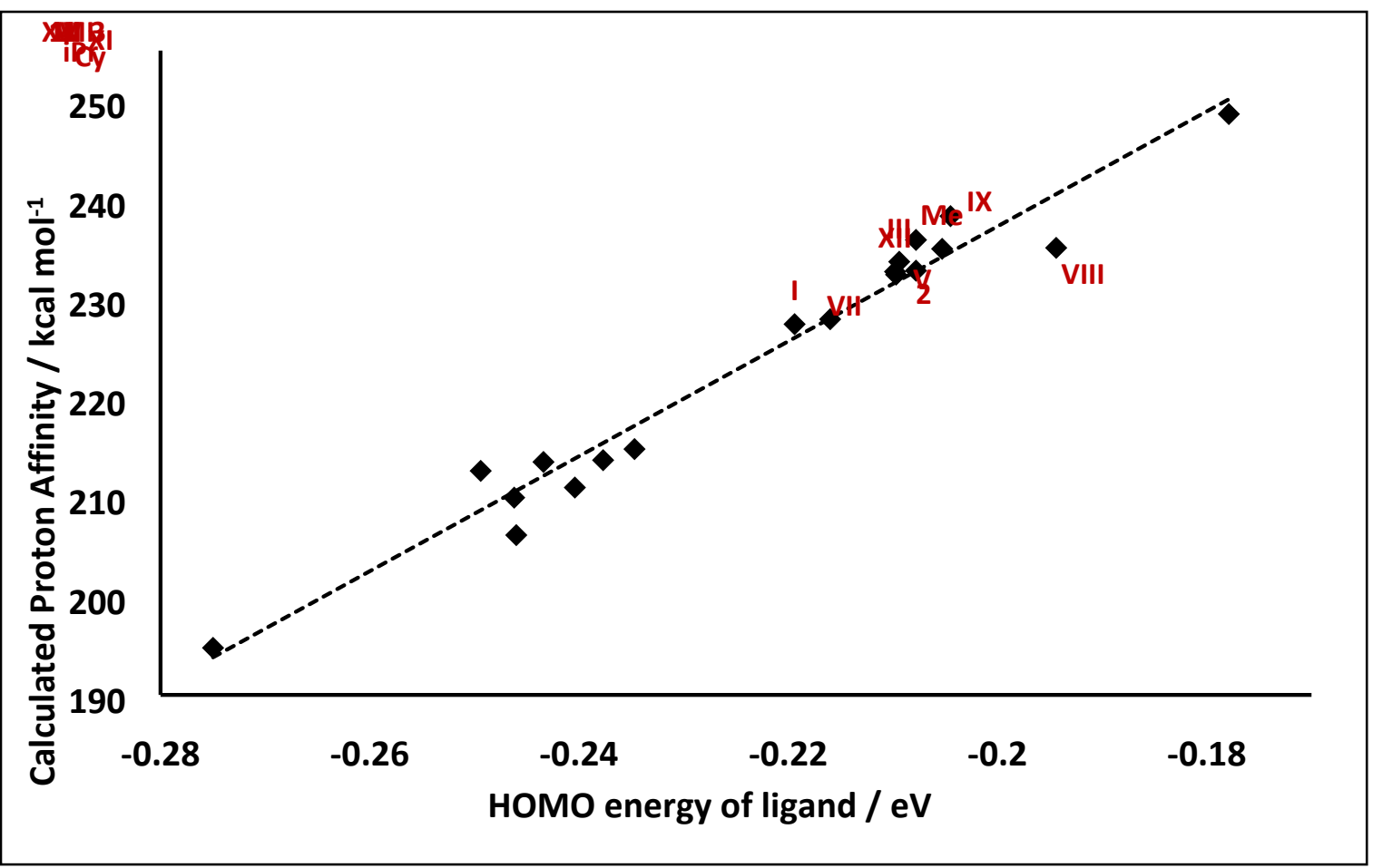

Figure S7: The calculated gas phase proton affinities and the HOMO energies for a series of carboranylphosphines.

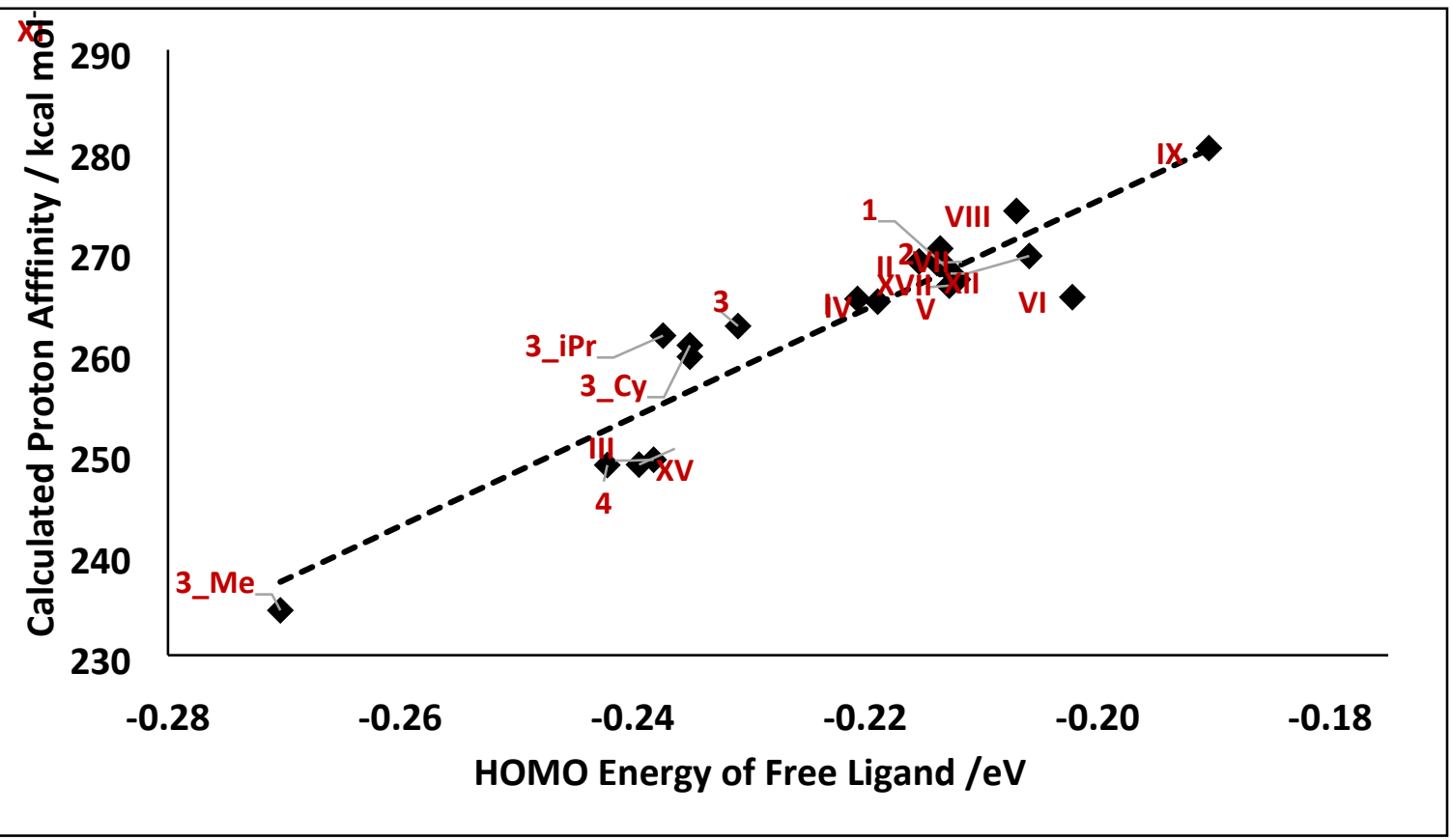

Figure S8: The calculated solution phase proton affinities and the HOMO energies for a series of carboranylphosphines. 


\section{References}

1) Jaguar v. 8.5 ; Schrödinger. Inc : New York, 2014.

2) a) Slater, J. C. Quantum Theory of Molecules and Solids, Vol. 4: The Self-Consistent Field for Molecules and Solids; McGraw-Hill: New York, 1974; b) Becke, A. D. Density-functional exchangeenergy approximation with correct asymptotic behaviour. Phys. Rev. A. 1988, 38, 3098-3100; c) Perdew, J. P. Density-functional approximation for the correlation energy of the inhomogeneous electron gas. Phys. Rev. B. 1986, 33, 8822-8824; d) Perdew, J. P. Erratum: Density-functional approximation for the correlation energy of the inhomogeneous electron gas. Phys. Rev. B. 1986, 34, 7406; e) Perdew, J. P.; Zunger, A. Self-interaction correlation to density-functional approximations for many-electron systems. Phys. Rev. B. 1981, 23, 5048- 5079.

3) Miertuš, S.; Scrocco, E.; Tomasi, J., Electrostatic interaction of a solute with a continuum. A direct utilization of $A B$ initio molecular potentials for the prevision of solvent effects. Chem. Phys. 1981, 55, 117-129.

4) Jover, J.; Fey, N.; Harvey, J. N.; Lloyd-Jones, G. C.; Orpen, A. G.; Owen-Smith, G. J. J.; Murray, P.; Hose, D. R. G.; Osborne, R.; Purdie, M. Expansion of the Ligand Knowledge Base for Monodentate P-Donor Ligands (LKB-P). Organometallics, 2010, 29, 6245-6258 and references cited therein.

5) NBO 5.0 Glendening, E.D.; Badenhoop, J.K.; Reed, A. E.; Carpenter, J. E.; Bohmann, J. A.; Morales C. M.; Weinhold, F. 2001, Madison.

6) Mennucci, B.; Tomasi, J.; Cammi, R.; Cheeseman, J. R.; Frisch, M. J.; Devlin, F. J.; Gabriel, S.; Stephens, P. J.; J. Phys. Chem. A, 2002, 106, 6102-6113.

7) Tomasi, J.; Mennucci, B.; Cammi, R.; Chem. Rev. 2005, 10, 2999-3094.

8) Senn, H. M.; Deubel, D. V.; Blöchl, P. E.; Togni, A.; Frenking, G.; J. Mol. Struct.(Theochem) 2000, 506, 233-242. 